\title{
CBOS
}

\section{Komunikat z badań nr 83/2018 Polityka państwa wobec rodzin - oceny i oczekiwania*}

Badania CBOS podsumowujące dorobek gabinetu Beaty Szydło po dwóch latach działalności pokazały, że polityka wobec rodziny należała do najmocniejszych stron jej rządu ${ }^{1}$. Kontynuację działań mających na celu wspieranie rodzin i ułatwienie realizacji planów prokreacyjnych zapowiedział rząd Mateusza Morawieckiego. Spośród przedstawionych na kwietniowej konwencji PiS propozycji wkrótce realizowany będzie program Dobry Start, przewidujący wypłacanie wszystkim uczniom raz w roku 300 zł wsparcia. Od roku 2019 mają być wdrażane rozwiązania składające się na program Mama plus: gwarancja wypłaty najniższej emerytury dla matek co najmniej czworga dzieci, darmowe leki dla kobiet w ciąży, udogodnienia dla mam-studentek (m.in. prawo do indywidualnego toku studiów), premia za szybkie urodzenie kolejnego dziecka. Wicepremier Beata Szydło zapowiedziała także bony na sport i kulturę dla młodzieży.

W majowym badaniu² zapytaliśmy Polaków o ich ocenę polityki rodzinnej rządu, w tym nowych propozycji.

\footnotetext{
* Źródło: Fundacja Centrum Badania Opinii Społecznej, ul. Świętojerska 5/7, 00-236 Warszawa, e-mail: sekretariat@cbos.pl; info@cbos.pl, http://www.cbos.pl.

${ }^{1}$ Por. komunikat CBOS „Bilans dokonań rządu po dwóch latach jego działalności”, listopad 2017 (oprac. B. Roguska).

2 Badanie „Aktualne problemy i wydarzenia” (336) przeprowadzono metodą wywiadów bezpośrednich (facetoface) wspomaganych komputerowo (CAPI) w dniach 10-17 maja 2018
} 
Ocena polityki państwa wobec rodziny

Wprowadzenie programu Rodzina 500 plus diametralnie zmieniło postrzeganie polityki państwa wobec rodziny. W badaniach CBOS realizowanych od 1996 do 2013 roku działania państwa wobec rodziny oceniane były jako dostateczne lub nawet niedostateczne. Niemal rok po wprowadzeniu programu Rodzina 500 plus dobrze lub nawet bardzo dobrze politykę państwa wobec rodziny oceniła ponad połowa badanych (52\%). Od tego czasu oceny polityki rodzinnej niewiele się już zmieniły: działania państwa w tej sferze docenia blisko połowa badanych (49\%).

Rys. 1. Ludzie różnie oceniają obecną politykę państwa wobec rodziny. Stosując skalę ocen od „bardzo dobrze” do "niedostatecznie”, proszę powiedzieć, jak ocenia Pan(i) obecną politykę państwa wobec rodziny?

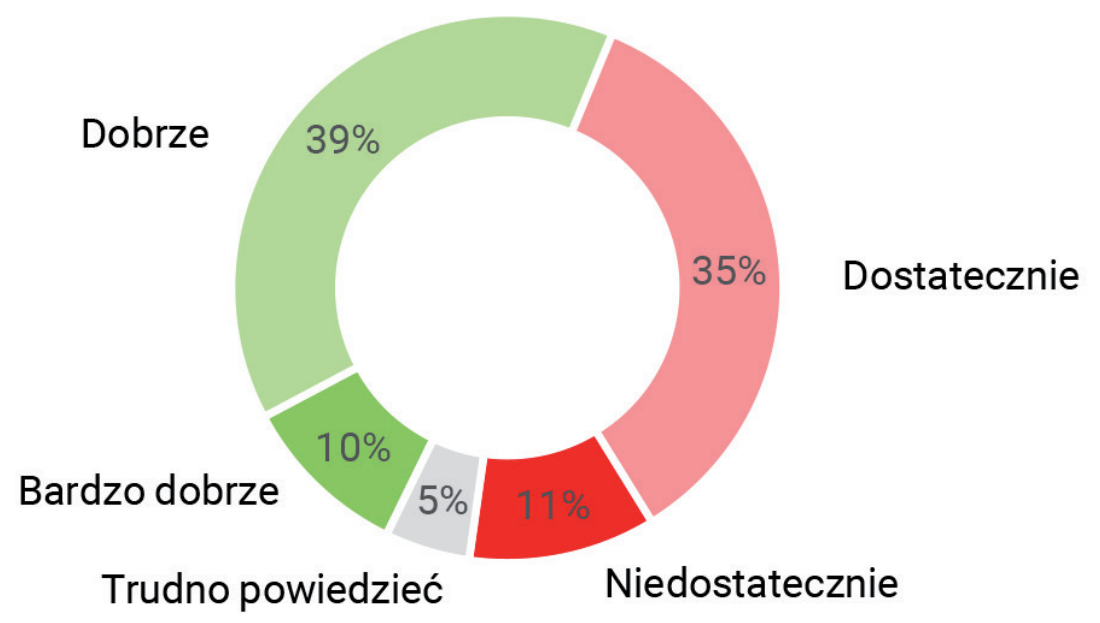

roku na liczącej 1121 osób reprezentatywnej próbie losowej dorosłych mieszkańców Polski. 
Tabela 1

\begin{tabular}{|l|c|c|c|c|c|c|c|c|c|}
\hline Ludzie różnie oceniają obecną politykę & \multicolumn{7}{|c|}{ Wskazania respondentów } \\
państwa wobec rodziny. Stosując skalę \\
\cline { 2 - 9 } $\begin{array}{l}\text { ocen od ,bardzo dobrze” do „niedosta- } \\
\text { tecznie”, proszę powiedzieć, jak ocenia }\end{array}$ & $\begin{array}{c}\text { IX } \\
\text { Pan(i) obecną politykę państwa wobec } \\
\text { rodziny? }\end{array}$ & II & II & IV & VII & III & V \\
2000 & 2006 & 2012 & 2013 & 2017 & 2018 \\
\cline { 2 - 10 } & 11 & 6 & 16 & 9 & 13 & 52 & 49 \\
\hline Dobrze lub bardzo dobrze & 47 & 41 & 45 & 33 & 51 & 34 & 35 \\
\hline Dostatecznie & 35 & 46 & 31 & 51 & 32 & 10 & 11 \\
\hline Niedostatecznie & 6 & 7 & 8 & 7 & 4 & 4 & 5 \\
\hline Trudno powiedzieć & & & & & & & \\
\hline $\begin{array}{l}\text { Średnia na skali od 2 do 5, na której } \\
\text { 2 oznacza ocenę niedostateczną, } \\
\text { a 5 - bardzo dobrą }\end{array}$ & 2,8 & 2,6 & 2,9 & 2,6 & 2,8 & 3,5 & 3,5 \\
\hline
\end{tabular}

Postrzeganie polityki państwa wobec rodziny zależy w głównej mierze od orientacji światopoglądowej ankietowanych: ich poglądów politycznych oraz religijności. Pozytywnym ocenom polityki rodzinnej sprzyjają prawicowe poglądy polityczne i częsty udział w praktykach religijnych. Podejmowane przez państwo działania na rzecz rodziny dobrze ocenia ogółem 72\% osób deklarujących prawicowe poglądy polityczne (w tym $20 \%$ bardzo dobrze) i tylko 33\% ankietowanych identyfikujących się z lewicą. Wśród osób kilka razy w tygodniu uczestniczących w praktykach religijnych aprobata polityki wobec rodziny sięga $68 \%$ (w tym $26 \%$ ocenia ją bardzo dobrze), wśród niepraktykujących - 33\%.

Biorąc pod uwagę podstawowe cechy społeczno-demograficzne można stwierdzić, że największe znaczenie dla postrzegania polityki państwa wobec rodzin ma wielkość miejsca zamieszkania. Najlepiej oceniają ją mieszkańcy wsi (57\% ocen dobrych i bardzo dobrych), najmniej zadowoleni są mieszkańcy największych miast (33\% ocen dobrych i bardzo dobrych).

Opinie o polityce państwa wobec rodziny różnicuje także korzystanie przez gospodarstwo domowe respondenta z programu Rodzina 500 plus. Lepiej niż przeciętnie działania rządu wobec rodziny oceniają osoby z gospodarstw domowych korzystających z tego programu, szczególnie tych, które otrzymują świadczenie wychowawcze na co najmniej dwoje dzieci. Najbardziej krytyczni w ocenach są badani mający dziecko w gospodarstwie domowym, ale nieotrzymujący na nie świadczenia wychowawczego. 
Tabela 2

\begin{tabular}{|c|c|c|c|c|c|c|}
\hline \multirow{3}{*}{$\begin{array}{l}\text { Korzystanie przez gospodarstwo domowe } \\
\text { z programu Rodzina } 500 \text { plus }\end{array}$} & \multicolumn{6}{|c|}{$\begin{array}{l}\text { Stosując skalę ocen od „bardzo do- } \\
\text { brze” do „niedostatecznie”, proszę } \\
\text { powiedzieć, jak ocenia Pan(i) obecną } \\
\text { politykę państwa wobec rodziny? }\end{array}$} \\
\hline & $\begin{array}{l}\tilde{N} \\
\tilde{D} \\
0 \\
0 \\
0 \\
0 \\
0 \\
0 \\
0\end{array}$ & $\begin{array}{l}\stackrel{N}{N} \\
\stackrel{0}{0} \\
\stackrel{0}{0}\end{array}$ & 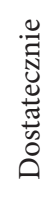 & 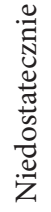 & 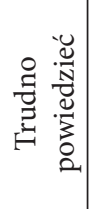 & \multirow[t]{2}{*}{$\begin{array}{l}\text { Średnia } \\
\text { na skali } \\
\text { od } 2 \text { do } 5\end{array}$} \\
\hline & \multicolumn{5}{|c|}{ w procentach } & \\
\hline Badani z gospodarstw domowych bez dzieci & 9 & 38 & 35 & 12 & 6 & 3,5 \\
\hline $\begin{array}{l}\text { Badani z gospodarstw domowych nieotrzymują- } \\
\text { cych świadczenia wychowawczego na dziecko }\end{array}$ & 6 & 32 & 34 & 20 & 8 & 3,3 \\
\hline $\begin{array}{l}\text { Badani z gospodarstw domowych otrzymujących } \\
\text { świadczenie wychowawcze na } 1 \text { dziecko }\end{array}$ & 14 & 44 & 36 & 4 & 2 & 3,7 \\
\hline $\begin{array}{l}\text { Badani z gospodarstw domowych } \\
\text { otrzymujących świadczenie wychowawcze } \\
\text { na co najmniej } 2 \text { dzieci }\end{array}$ & 15 & 50 & 31 & 3 & 1 & 3,8 \\
\hline
\end{tabular}

\section{Jak wspierać rodziny?}

Prowadzone w kolejnych latach badania pokazują, jak zmienia się sposób myślenia Polaków o polityce rodzinnej państwa. Jeszcze w ubiegłej dekadzie dominowało przekonanie, że państwo powinno wspierać tylko rodziny znajdujące się w trudnym położeniu materialnym. Od kilku lat przeważa pogląd, że wsparcie ze strony państwa powinno obejmować wszystkie rodziny wychowujące dzieci. O ile jednak przed wejściem w życie programu Rodzina 500 plus opinię tę podzielało $60 \%$ badanych, o tyle obecnie istotnie mniej - 54\%. 
Tabela 3

\begin{tabular}{|l|c|c|c|c|c|c|}
\hline \multirow{2}{*}{$\begin{array}{l}\text { Możliwe są różne podejścia i różne } \\
\text { formy polityki wspierania rodzin } \\
\text { przez państwo. Czy, Pana(i) zda- } \\
\text { niem, państwo powinno wspierać: }\end{array}$} & \multicolumn{5}{|c|}{$\begin{array}{c}\text { Wskazania respondentów } \\
\text { według terminów badań }\end{array}$} \\
\cline { 2 - 6 } & II 2000 & II 2006 & IV 2012 & II 2016 & V 2018 \\
\hline $\begin{array}{l}\text { - wszystkie rodziny wychowujące } \\
\text { dzieci }\end{array}$ & 36 & 43 & 60 & 60 & 54 \\
\hline $\begin{array}{l}\text { - tylko rodziny wychowujące } \\
\text { dzieci znajdujące się w trudnej } \\
\text { sytuacji materialnej }\end{array}$ & 61 & 53 & 37 & 38 & 42 \\
\hline $\begin{array}{l}\text { - państwo w ogóle nie powinno } \\
\text { wspierać rodzin }\end{array}$ & 1 & 1 & 1 & 0 & - \\
\hline Trudno powiedzieć & 2 & 3 & 2 & 2 & 4 \\
\hline
\end{tabular}

Opinie $\mathrm{w}$ tej kwestii różnicuje przede wszystkim posiadanie dzieci w gospodarstwie domowym. O ile badani z gospodarstw domowych z dziećmi w zdecydowanej większości (71\%) sądzą, że państwo powinno wpierać wszystkie rodziny wychowujące potomstwo, o tyle opinie respondentów z gospodarstw domowych bez dzieci są mniej jednoznaczne. Co więcej, nieco częściej są oni zdania, że państwo powinno wspierać tylko rodziny znajdujące w trudnej sytuacji materialnej (51\%), niż że powinno pomagać wszystkim rodzinom wychowującym dzieci (44\%).

Poglądy dotyczące jednego z podstawowych założeń polityki wobec rodzin wyraźnie różnicuje wiek. Wsparcia ze strony państwa dla wszystkich rodzin wychowujących potomstwo oczekują przede wszystkim badani w wieku od 25 do 34 lat (68\%) oraz od 35 do 44 lat (70\%). Warto wspomnieć, że większość osób z tych kategorii wiekowych ma dzieci w swoim gospodarstwie domowym. Najwięcej zwolenników ograniczenia wsparcia tylko do rodzin znajdujących się $\mathrm{w}$ trudnej sytuacji materialnej jest wśród najstarszych respondentów - w wieku 65+ (60\%).

W ocenie społecznej państwo powinno przede wszystkim mieć na względzie zapewnienie rodzinom z dziećmi odpowiednich warunków bytowych. 
Rys. 2. Jakie formy wspierania rodziny, obecnie funkcjonujące lub postulowane, uważa Pan(i) za najbardziej przydatne i mogące zachęcać do posiadania dzieci?

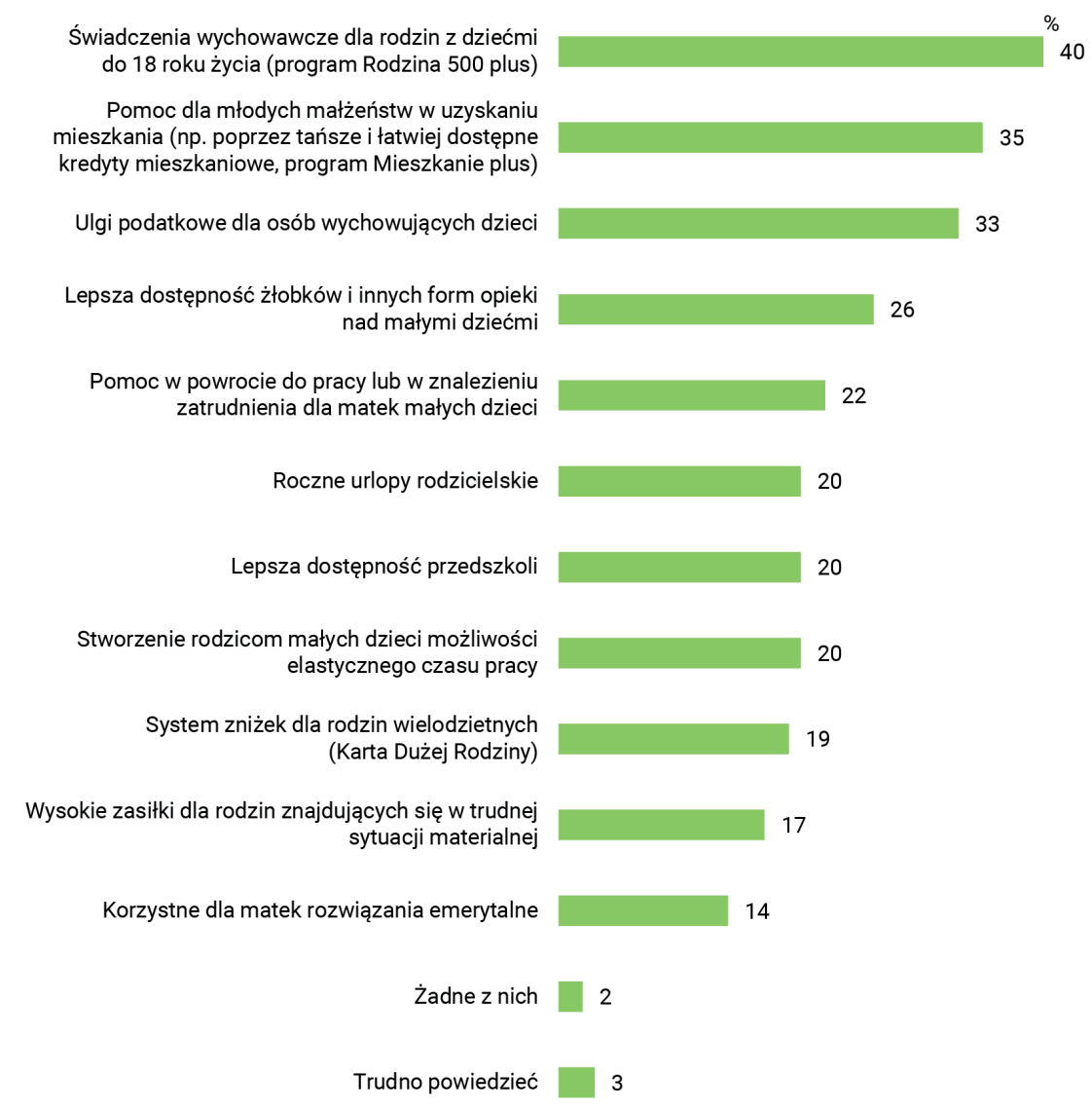

Wśród trzech najbardziej przydatnych instrumentów wsparcia rodzin, mogących zachęcać do posiadania dzieci wymieniano kolejno: świadczenie wychowawcze z programu Rodzina 500 plus, pomoc dla młodych małżeństw w uzyskaniu mieszkania (np. poprzez tanie i dostępne kredyty lub realizację programu Mieszkanie plus) oraz ulgi podatkowe dla rodzin $\mathrm{z}$ dziećmi. Stosunkowo dużo osób wskazało ponadto na potrzebę zagwarantowania lepszej dostępności żłobków i innych form opieki nad małymi dziećmi. Na potrzebę rozwoju różnych form opieki nad małymi dziećmi wskazywano częściej niż na poprawę dostępności przedszkoli. 
Osoby z gospodarstw domowych z dziećmi częściej niż ogół badanych wśród najbardziej przydatnych sposobów wspierania rodzin wymieniają świadczenie wychowawcze z programu Rodzina 500 plus oraz ulgi podatkowe dla osób wychowujących dzieci, rzadziej natomiast wskazują na pomoc dla młodych małżeństw w uzyskaniu mieszkania.

\section{Tabela 4}

Jakie formy wspierania rodziny, obecnie funkcjonujące lub postulowane, uważa Pan(i) za najbardziej przydatne i mogące zachęcać do posiadania dzieci?

\begin{tabular}{|c|c|c|}
\hline $\begin{array}{l}\text { Świadczenia wychowawcze dla } \\
\text { rodzin z dziećmi do } 18 \text { roku } \\
\text { życia (program Rodzina } 500 \\
\text { plus) }\end{array}$ & 49 & 36 \\
\hline $\begin{array}{l}\text { Ulgi podatkowe dla osób wycho- } \\
\text { wujących dzieci }\end{array}$ & 37 & 30 \\
\hline $\begin{array}{l}\text { Pomoc dla młodych małżeństw } \\
\text { w uzyskaniu mieszkania } \\
\text { (np. poprzez tańsze i łatwiej } \\
\text { dostępne kredyty mieszkaniowe, } \\
\text { program Mieszkanie plus) }\end{array}$ & 29 & 38 \\
\hline $\begin{array}{l}\text { Lepsza dostępność żłobków i } \\
\text { innych form opieki nad małymi } \\
\text { dziećmi }\end{array}$ & 25 & 27 \\
\hline Lepsza dostępność przedszkoli & 22 & 19 \\
\hline $\begin{array}{l}\text { System zniżek dla rodzin wielo- } \\
\text { dzietnych (Karta Dużej Rodziny) }\end{array}$ & 22 & 18 \\
\hline Roczne urlopy rodzicielskie & 21 & 19 \\
\hline $\begin{array}{l}\text { Pomoc w powrocie do pracy } \\
\text { lub w znalezieniu zatrudnienia } \\
\text { dla matek małych dzieci }\end{array}$ & 21 & 23 \\
\hline $\begin{array}{l}\text { Stworzenie rodzicom małych } \\
\text { dzieci możliwości elastycznego } \\
\text { czasu pracy }\end{array}$ & 21 & 19 \\
\hline $\begin{array}{l}\text { Wysokie zasiłki dla rodzin znaj- } \\
\text { dujących się w trudnej sytuacji } \\
\text { materialnej }\end{array}$ & 18 & 17 \\
\hline $\begin{array}{l}\text { Korzystne dla matek rozwiązania } \\
\text { emerytalne }\end{array}$ & 14 & 14 \\
\hline Żadne z nich & 1 & 2 \\
\hline Trudno powiedzieć & 2 & 4 \\
\hline
\end{tabular}

w procentach \begin{tabular}{l|l}
$\begin{array}{c}\text { Badani z gospodarstw } \\
\text { domowych } \mathrm{z} \text { dziećmi }\end{array}$ & $\begin{array}{c}\text { Badani z gospodarstw } \\
\text { domowych bez dzieci }\end{array}$
\end{tabular} 
Świadczenie wychowawcze z programu Rodzina 500 plus jest uznawane za najlepszy lub jeden $z$ najlepszych sposobów wspierania rodzin niemal we wszystkich grupach społecznodemograficznych. O przydatności tej formy zapewniania wsparcia rodzinom i zachęcania do posiadania dzieci najczęściej mówią mieszkańcy wsi (46\%, a zwłaszcza rolnicy - 62\%), osoby z wykształceniem podstawowym lub gimnazjalnym (45\%) i zasadniczym zawodowym (46\%), respondenci najsłabiej sytuowani - o miesięcznych dochodach per capita poniżej 900 zł (50\%). Zdecydowanie najrzadziej jako przydatną określają ją mieszkańcy dużych, co najmniej półmilionowych miast (17\%). Ta grupa badanych dość mocno wyróżnia się na tle ogółu ankietowanych pod względem preferencji dotyczących instrumentów polityki rodzinnej. Mieszkańcy dużych miast częściej niż przeciętnie - obok ulg podatkowych dla osób wychowujących dzieci (40\%) - za istotne uznają instrumenty służące ułatwieniu godzenia pracy zawodowej i opieki nad dziećmi: lepszy dostęp do żłobków i innych form opieki nad małymi dziećmi (39\%), lepszy dostęp do przedszkoli (35\%), a także stworzenie rodzicom małych dzieci możliwości elastycznego czasu pracy (28\%). Potrzebę rozwijania tego rodzaju form wspierania rodzin częściej dostrzegają także osoby najlepiej wykształcone i sytuowane (z wykształceniem wyższym, o miesięcznych dochodach per capita od 2500 zł wzwyż). Takie zróżnicowanie pokazuje, w jak dużym stopniu preferencje dotyczące instrumentów polityki rodzinnej zależą od stylu życia, sytuacji materialnej i aspiracji zawodowych.

\section{Poparcie dla nowych propozycji wspierania rodzin}

Wszystkie zapowiedziane przez rząd działania mające na celu wpieranie rodzin spotykają się z dość powszechną akceptacją społeczną (na poziomie od $75 \%$ w przypadku programu Dobry Start, do $89 \%$ w przypadku ułatwień dla matek-studentek). Poparcie dla tych zmian jest także w stosunkowo niedużym stopniu zróżnicowane w zależności od cech społecznodemograficznych badanych. Wszystkie proponowane rozwiązania budzą aprobatę we wszystkich uwzględnionych $\mathrm{w}$ analizach grupach społecznodemograficznych. 
Rys. 3. Rząd zapowiada nowe rozwiązania, które mają służyć wspieraniu rodzin i zachęcać do posiadania dzieci. Czy Pan(i) popiera:

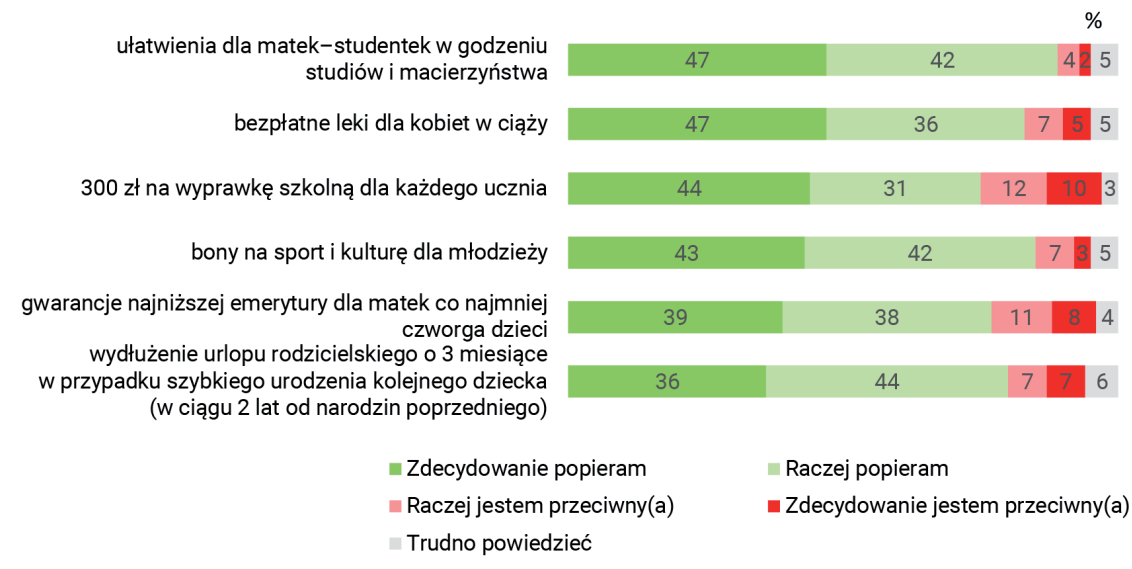

Większość badanych (66\%) popiera co najmniej 5 z 6 rozwiązań. Średnio deklarowano aprobatę dla 4,7 propozycji.

Rys. 4. Liczba popieranych rozwiązań

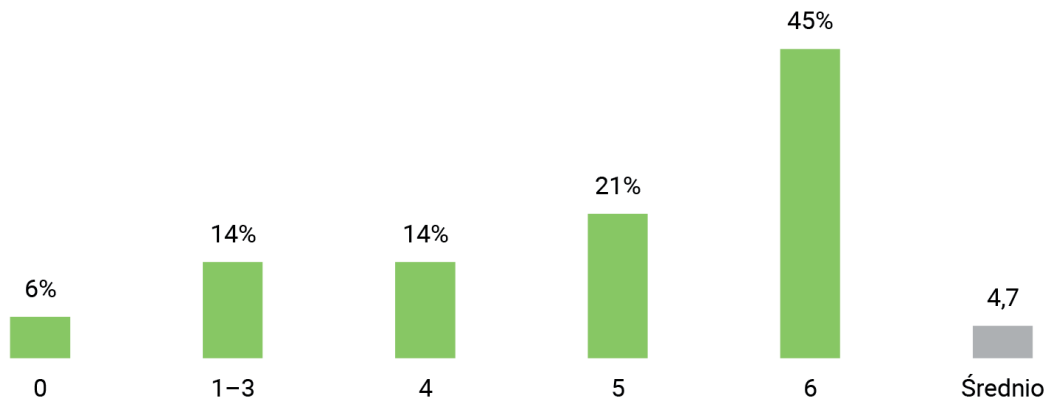

Stosunkowo najrzadziej poparcie dla zapowiadanych rozwiązań wyrażali mieszkańcy największych miast (średnio dla 4,1 z nich), osoby z wykształceniem wyższym $(4,3)$, respondenci stosunkowo dobrze sytuowani - o miesięcznych dochodach per capita od 2500 zł wzwyż $(4,4)$. W grupach społeczno-zawodowych nieco mniejszą aprobatę wyrażali: kadra kierownicza i specjaliści $(4,4)$, średni personel, technicy $(4,2)$, właściciele firm $(4,2)$ oraz uczniowie i studenci $(4,2)$. Stosunkowo mniej przychylnie na przedstawione propozycje wspierania rodzin i dzietności reagowały także osoby nieuczestniczące w praktykach religijnych $(4,1)$. 
Za najbardziej potrzebne rozwiązania spośród sześciu zapowiadanych uznawane są gwarancje najniższej emerytury dla matek co najmniej czworga dzieci oraz 300 zł na wyprawkę szkolną dla każdego ucznia. Za stosunkowo najmniej potrzebne - bony na sport i kulturę dla młodzieży.

Rys. 5. Które z tych rozwiązań byłyby, Pana(i) zdaniem, najbardziej potrzebne?

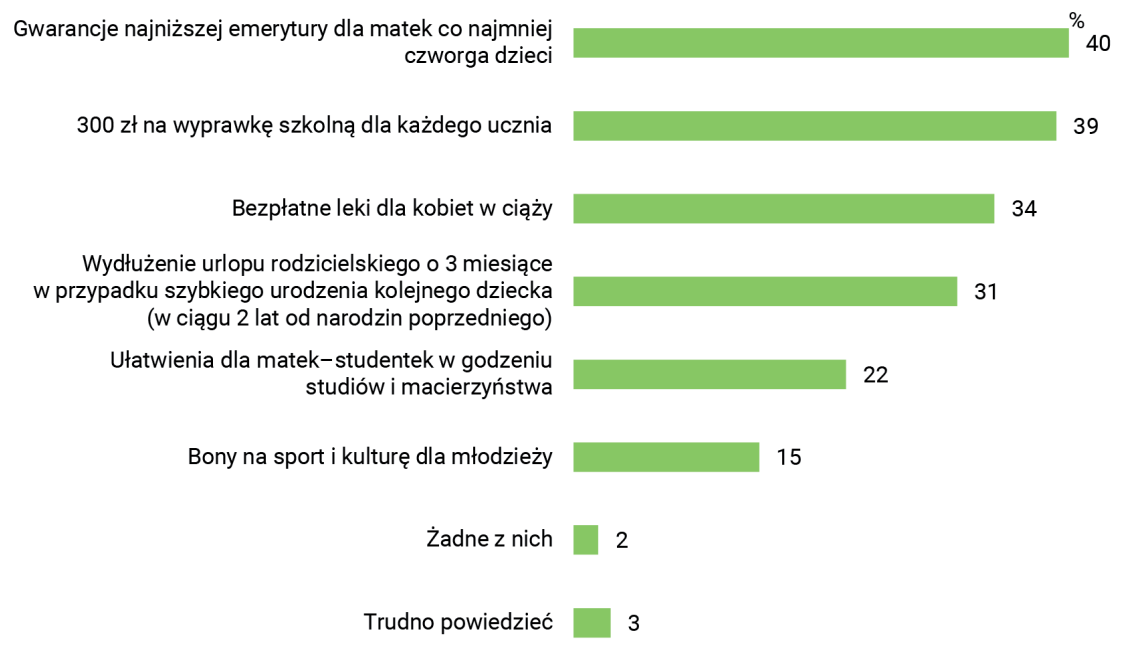

Wchodzący wkrótce w życie program Dobry Start oraz zapowiedzi realizacji programu Mama plus spotykają się generalnie z przychylnym przyjęciem społecznym i dobrze wpisują się w dotychczasową politykę rządu wobec rodzin. Polacy i sami zainteresowani oczekują od państwa przede wszystkim zapewnienia rodzinom wychowującym dzieci odpowiednich warunków bytowych, głównie poprzez świadczenia wychowawcze z programu Rodzina 500 plus, a także ulgi podatkowe na dzieci oraz odpowiednią politykę mieszkaniową. Oczekiwania społeczne dotyczą także rozwiązań służących ułatwieniu godzenia pracy zawodowej i opieki nad dziećmi. Poprawa dostępu do żłobków i innych form opieki nad małymi dziećmi oraz dostępu do przedszkoli i większe możliwości korzystania z elastycznego czasu pracy dla rodziców małych dzieci są szczególnie istotne dla mieszkańców dużych miast, dla osób z wykształceniem wyższym oraz lepiej niż przeciętnie sytuowanych.

Opracowała Beata Roguska 


\section{Aneks}

TABELA 1

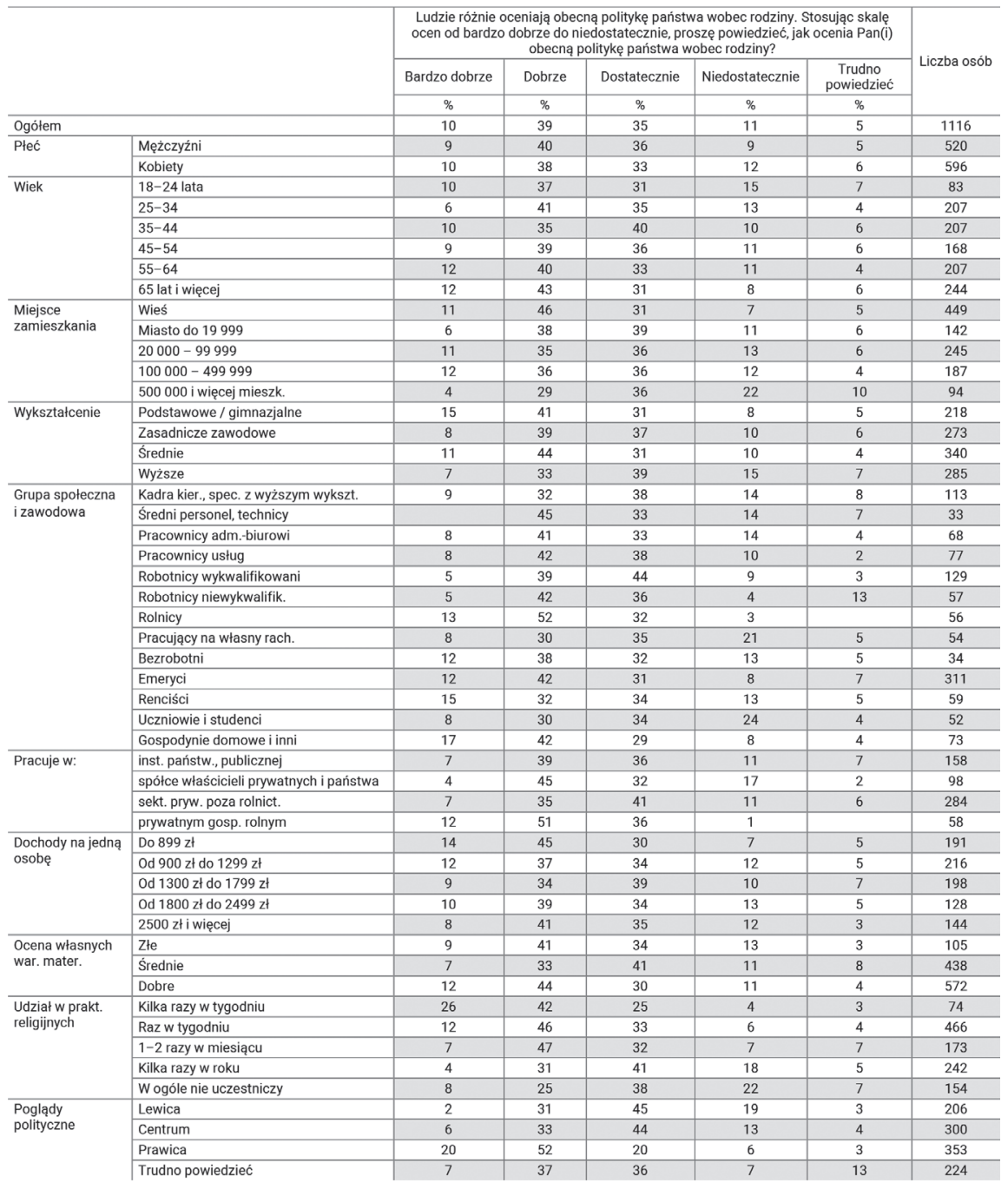


TABELA 2

\begin{tabular}{|c|c|c|c|c|c|}
\hline & & \multicolumn{3}{|c|}{ Czy, Pana(i) zdaniem, państwo powinno wspierać: } & \multirow{3}{*}{ Liczba osób } \\
\hline & & $\begin{array}{l}\text { wszystkie rodziny } \\
\text { wychowujące dzieci }\end{array}$ & $\begin{array}{l}\text { tylko rodziny wychowujące } \\
\text { dzieci znajdujące się w trudnej } \\
\text { sytuacji materialnej }\end{array}$ & $\begin{array}{c}\text { Trudno } \\
\text { powiedzieć }\end{array}$ & \\
\hline & & $\%$ & $\%$ & $\%$ & \\
\hline \multicolumn{2}{|l|}{ Ogöłem } & 54 & 42 & 4 & 1115 \\
\hline \multirow[t]{2}{*}{ Płeć } & Mężczyźni & 50 & 46 & 4 & 520 \\
\hline & Kobiety & 57 & 39 & 4 & 596 \\
\hline \multirow[t]{6}{*}{ Wiek } & 18-24lata & 54 & 42 & 4 & 83 \\
\hline & $25-34$ & 68 & 29 & 4 & 206 \\
\hline & $35-44$ & 70 & 25 & 5 & 207 \\
\hline & $45-54$ & 49 & 46 & 5 & 169 \\
\hline & $55-64$ & 48 & 49 & 3 & 207 \\
\hline & 65 lat i więcej & 36 & 60 & 4 & 244 \\
\hline \multirow{5}{*}{$\begin{array}{l}\text { Miejsce } \\
\text { zamieszkania }\end{array}$} & Wies & 55 & 42 & 3 & 448 \\
\hline & Miasto do 19999 & 48 & 45 & 7 & 142 \\
\hline & $20000-99999$ & 57 & 40 & 3 & 245 \\
\hline & $100000-499999$ & 48 & 44 & 8 & 187 \\
\hline & $500000 \mathrm{i}$ więcej mieszk. & 58 & 39 & 3 & 94 \\
\hline \multirow[t]{4}{*}{ Wykształcenie } & Podstawowe / gimnazjalne & 45 & 50 & 6 & 218 \\
\hline & Zasadnicze zawodowe & 55 & 41 & 3 & 273 \\
\hline & Średnie & 51 & 45 & 4 & 339 \\
\hline & Wyższe & 62 & 34 & 4 & 286 \\
\hline \multirow{13}{*}{$\begin{array}{l}\text { Grupa społeczna } \\
\text { i zawodowa }\end{array}$} & Kadra kier., spec. z wyższym wykszt. & 64 & 33 & 3 & 113 \\
\hline & Średni personel, technicy & 39 & 56 & 4 & 33 \\
\hline & Pracownicy adm.-biurowi & 67 & 27 & 5 & 68 \\
\hline & Pracownicy usług & 69 & 29 & 2 & 77 \\
\hline & Robotnicy wykwalifikowani & 58 & 39 & 3 & 128 \\
\hline & Robotnicy niewykwalifik. & 63 & 34 & 3 & 57 \\
\hline & Rolnicy & 52 & 41 & 7 & 56 \\
\hline & Pracujący na własny rach. & 61 & 35 & 5 & 55 \\
\hline & Bezrobotni & 57 & 38 & 5 & 34 \\
\hline & Emeryci & 39 & 57 & 4 & 311 \\
\hline & Renciści & 35 & 57 & 8 & 59 \\
\hline & Uczniowie i studenci & 48 & 44 & 8 & 52 \\
\hline & Gospodynie domowe i inni & 75 & 23 & 1 & 73 \\
\hline \multirow[t]{4}{*}{ Pracuje w: } & inst. panstw., publicznej & 59 & 37 & 4 & 158 \\
\hline & spółce właścicieli prywatnych i państwa & 53 & 42 & 5 & 98 \\
\hline & sekt. pryw. poza rolnict. & 66 & 31 & 2 & 283 \\
\hline & prywatnym gosp. rolnym & 56 & 37 & 6 & 58 \\
\hline \multirow{5}{*}{$\begin{array}{l}\text { Dochody na jedną } \\
\text { osobę }\end{array}$} & Do 899 zt & 62 & 34 & 4 & 191 \\
\hline & Od $900 \mathrm{zł}$ do $1299 \mathrm{zł}$ & 54 & 42 & 4 & 215 \\
\hline & Od 1300 zł do $1799 \mathrm{zt}$ & 48 & 49 & 3 & 197 \\
\hline & Od $1800 \mathrm{zł} \mathrm{do} 2499 \mathrm{zł}$ & 56 & 37 & 7 & 129 \\
\hline & 2500 złi więcej & 49 & 48 & 2 & 144 \\
\hline \multirow{3}{*}{$\begin{array}{l}\text { Ocena własnych } \\
\text { war. mater. }\end{array}$} & Złe & 44 & 51 & 4 & 105 \\
\hline & Średnie & 50 & 45 & 5 & 438 \\
\hline & Dobre & 58 & 38 & 3 & 573 \\
\hline \multirow{5}{*}{$\begin{array}{l}\text { Udział w prakt. } \\
\text { religijnych }\end{array}$} & Kilka razy $w$ tygodniu & 54 & 40 & 7 & 74 \\
\hline & Raz w tygodniu & 56 & 41 & 3 & 466 \\
\hline & $1-2$ razy w miesiącu & 53 & 43 & 3 & 173 \\
\hline & Kilka razy w roku & 53 & 43 & 4 & 241 \\
\hline & W ogóle nie uczestniczy & 49 & 44 & 7 & 155 \\
\hline \multirow{4}{*}{$\begin{array}{l}\text { Poglądy } \\
\text { polityczne }\end{array}$} & Lewica & 52 & 45 & 3 & 207 \\
\hline & Centrum & 54 & 40 & 5 & 299 \\
\hline & Prawica & 55 & 43 & 2 & 353 \\
\hline & Trudno powiedzieć & 54 & 41 & 6 & 224 \\
\hline
\end{tabular}


TABELA 3

\begin{tabular}{|c|c|c|c|c|c|c|c|c|}
\hline & & \multicolumn{6}{|c|}{$\begin{array}{l}\text { Jakie formy wspierania rodziny, obecnie funkcjonujace lub postulowane, uważa Pan(i) za najbardziej } \\
\text { przydatne i mogące zachęcać do posiadania dzieci? }\end{array}$} & \multirow{3}{*}{$\begin{array}{l}\text { Liczba } \\
\text { osób }\end{array}$} \\
\hline & & $\begin{array}{c}\text { Roczne } \\
\text { urlopy } \\
\text { rodzicielskie }\end{array}$ & \begin{tabular}{|c} 
Pomoc dla młodych \\
małżeństw w \\
uzyskaniu mieszkania \\
(np. poprzez tańsze \\
i tatwiej dosteppne \\
kredyty mieszkaniowe, \\
program Mieszkanie \\
plus)
\end{tabular} & $\begin{array}{l}\text { Lepsza } \\
\text { dosteepność } \\
\text { żłobków } \\
\text { i innych form } \\
\text { opieki nad } \\
\text { małymi } \\
\text { dziećmi }\end{array}$ & $\begin{array}{l}\text { Lepsza } \\
\text { dostępność } \\
\text { przedszkoli }\end{array}$ & $\begin{array}{c}\text { Świadczenia } \\
\text { wychowawcze dla } \\
\text { rodzin z dziećmi } \\
\text { do } 18 \text { roku życia } \\
\text { (program Rodzina } \\
500 \text { plus) }\end{array}$ & $\begin{array}{c}\text { Pomoc } \\
\text { w powrocie } \\
\text { do pracy lub } \\
\text { w znalezieniu } \\
\text { zatrudnienia } \\
\text { dla matek } \\
\text { malych dzieci }\end{array}$ & \\
\hline & & $\%$ & $\%$ & $\%$ & $\%$ & $\%$ & $\%$ & \\
\hline \multicolumn{2}{|l|}{ Ogółem } & 20 & 35 & 26 & 20 & 40 & 22 & 1116 \\
\hline \multirow[t]{2}{*}{ Płeć } & Mężczyźni & 15 & 34 & 26 & 17 & 41 & 22 & 521 \\
\hline & Kobiety & 24 & 35 & 26 & 23 & 40 & 23 & 595 \\
\hline \multirow[t]{6}{*}{ Wiek } & 18-24 lata & 28 & 37 & 22 & 18 & 36 & 23 & 83 \\
\hline & $25-34$ & 22 & 32 & 27 & 20 & 41 & 27 & 208 \\
\hline & $35-44$ & 18 & 39 & 25 & 18 & 43 & 22 & 207 \\
\hline & $45-54$ & 21 & 31 & 25 & 20 & 38 & 24 & 169 \\
\hline & $55-64$ & 17 & 33 & 26 & 21 & 39 & 21 & 206 \\
\hline & 65 lat $\mathrm{i}$ więcej & 17 & 37 & 28 & 23 & 41 & 19 & 244 \\
\hline \multirow{5}{*}{$\begin{array}{l}\text { Miejsce } \\
\text { zamieszkania }\end{array}$} & Wieś & 19 & 31 & 22 & 17 & 46 & 23 & 447 \\
\hline & Miasto do 19999 & 18 & 37 & 28 & 24 & 41 & 18 & 142 \\
\hline & $20000-99999$ & 24 & 37 & 25 & 20 & 38 & 26 & 245 \\
\hline & $100000-499999$ & 17 & 40 & 29 & 20 & 41 & 23 & 188 \\
\hline & 500000 i więcej mieszk. & 20 & 31 & 39 & 35 & 17 & 20 & 94 \\
\hline \multirow[t]{4}{*}{ Wykształcenie } & Podstawowe / gimnazjalne & 15 & 34 & 19 & 18 & 45 & 27 & 217 \\
\hline & Zasadnicze zawodowe & 17 & 36 & 19 & 16 & 46 & 22 & 272 \\
\hline & Średnie & 20 & 38 & 28 & 19 & 39 & 23 & 340 \\
\hline & Wyższe & 26 & 31 & 35 & 28 & 33 & 19 & 288 \\
\hline \multirow{13}{*}{$\begin{array}{l}\text { Grupa } \\
\text { społeczna } \\
\text { i zawodowa }\end{array}$} & $\begin{array}{l}\text { Kadra kier., spec. } \\
\text { z wyższym wykszt. }\end{array}$ & 28 & 29 & 38 & 25 & 27 & 17 & 114 \\
\hline & Średni personel, technicy & 20 & 45 & 23 & 15 & 49 & 32 & 33 \\
\hline & Pracownicy adm.biurowi & 36 & 34 & 29 & 24 & 44 & 18 & 68 \\
\hline & Pracownicy usług & 16 & 44 & 29 & 17 & 38 & 26 & 78 \\
\hline & Robotnicy wykwalifikowani & 17 & 35 & 23 & 23 & 41 & 24 & 129 \\
\hline & Robotnicy niewykwalifik. & 16 & 28 & 18 & 17 & 47 & 23 & 56 \\
\hline & Rolnicy & 25 & 28 & 13 & 13 & 62 & 21 & 56 \\
\hline & Pracujący na własny rach. & 11 & 35 & 30 & 20 & 31 & 24 & 55 \\
\hline & Bezrobotni & 24 & 31 & 24 & 23 & 30 & 22 & 34 \\
\hline & Emeryci & 18 & 34 & 29 & 22 & 40 & 20 & 310 \\
\hline & Renciści & 14 & 43 & 10 & 20 & 48 & 25 & 59 \\
\hline & Uczniowie i studenci & 24 & 35 & 28 & 13 & 31 & 32 & 52 \\
\hline & Gospodynie domowe i inni & 15 & 36 & 21 & 16 & 46 & 24 & 73 \\
\hline \multirow[t]{4}{*}{ Pracuje w: } & inst. państw., publicznej & 29 & 29 & 29 & 25 & 39 & 27 & 158 \\
\hline & $\begin{array}{l}\text { spółce właścicieli } \\
\text { prywatnych i państwa }\end{array}$ & 21 & 37 & 19 & 17 & 36 & 15 & 98 \\
\hline & sekt. pryw. poza rolnict. & 16 & 37 & 31 & 22 & 38 & 22 & 285 \\
\hline & prywatnym gosp. rolnym & 22 & 25 & 13 & 12 & 66 & 21 & 58 \\
\hline \multirow{5}{*}{$\begin{array}{l}\text { Dochody na } \\
\text { jedną osobę }\end{array}$} & Do 899 zł & 18 & 33 & 24 & 16 & 50 & 23 & 191 \\
\hline & Od $900 \mathrm{zt}$ do $1299 \mathrm{zt}$ & 21 & 41 & 19 & 18 & 43 & 24 & 216 \\
\hline & Od 1300 zł do $1799 \mathrm{zt}$ & 24 & 36 & 24 & 22 & 40 & 23 & 198 \\
\hline & Od 1800 zł do 2499 zł & 23 & 40 & 37 & 25 & 33 & 24 & 128 \\
\hline & 2500 zł i więcej & 17 & 36 & 43 & 27 & 29 & 19 & 144 \\
\hline \multirow{3}{*}{$\begin{array}{l}\text { Ocena } \\
\text { własnych war. } \\
\text { mater. }\end{array}$} & Złe & 19 & 32 & 18 & 10 & 42 & 22 & 104 \\
\hline & Średnie & 18 & 36 & 23 & 20 & 39 & 23 & 440 \\
\hline & Dobre & 21 & 34 & 30 & 23 & 41 & 22 & 573 \\
\hline \multirow{5}{*}{$\begin{array}{l}\text { Udział w prakt. } \\
\text { religijnych }\end{array}$} & Kilka razy w tygodniu & 22 & 31 & 16 & 19 & 46 & 20 & 74 \\
\hline & Raz w tygodniu & 22 & 37 & 26 & 19 & 46 & 22 & 466 \\
\hline & $1-2$ razy w miesiącu & 15 & 31 & 20 & 19 & 38 & 22 & 173 \\
\hline & Kilka razy w roku & 17 & 38 & 27 & 18 & 41 & 26 & 241 \\
\hline & W ogóle nie uczestniczy & 21 & 29 & 35 & 30 & 23 & 22 & 155 \\
\hline \multirow{4}{*}{$\begin{array}{l}\text { Poglądy } \\
\text { polityczne }\end{array}$} & Lewica & 21 & 30 & 33 & 27 & 31 & 21 & 207 \\
\hline & Centrum & 21 & 37 & 28 & 18 & 34 & 25 & 299 \\
\hline & Prawica & 18 & 37 & 25 & 19 & 52 & 21 & 355 \\
\hline & Trudno powiedzieć & 20 & 31 & 18 & 21 & 41 & 23 & 224 \\
\hline
\end{tabular}


TABELA 4

\begin{tabular}{|c|c|c|c|c|c|}
\hline & & \multicolumn{3}{|c|}{$\begin{array}{c}\text { Rząd zapowiada nowe rozwiązania, które mają służyć wspieraniu rodzin } \\
\text { i zachęcać do posiadania dzieci. Czy Pan(i) popiera } \\
\text { bezpłatne leki dla kobiet w ciąży? }\end{array}$} & \multirow{3}{*}{ Liczba osób } \\
\hline & & Popieram & Jestem przeciwny(a) & Trudno powiedzieć & \\
\hline & & $\%$ & $\%$ & $\%$ & \\
\hline \multicolumn{2}{|l|}{ Ogółem } & 83 & 12 & 5 & 1117 \\
\hline \multirow[t]{2}{*}{ Płeć } & Mężczyźni & 83 & 12 & 5 & 521 \\
\hline & Kobiety & 84 & 12 & 4 & 596 \\
\hline \multirow[t]{6}{*}{ Wiek } & 18-24 lata & 78 & 16 & 6 & 83 \\
\hline & $25-34$ & 85 & 10 & 5 & 208 \\
\hline & $35-44$ & 88 & 9 & 3 & 207 \\
\hline & $45-54$ & 82 & 12 & 6 & 168 \\
\hline & $55-64$ & 81 & 15 & 4 & 207 \\
\hline & 65 lat $\mathrm{i}$ więcej & 83 & 12 & 5 & 244 \\
\hline \multirow{5}{*}{$\begin{array}{l}\text { Miejsce } \\
\text { zamieszkania }\end{array}$} & Wieś & 84 & 9 & 6 & 449 \\
\hline & Miasto do 19999 & 83 & 14 & 3 & 142 \\
\hline & $20000-99999$ & 85 & 12 & 3 & 244 \\
\hline & $100000-499999$ & 82 & 15 & 4 & 188 \\
\hline & 500000 i więcej mieszk. & 78 & 14 & 8 & 94 \\
\hline \multirow[t]{4}{*}{ Wykształcenie } & Podstawowe/gimnazjalne & 84 & 11 & 5 & 218 \\
\hline & Zasadnicze zawodowe & 84 & 10 & 6 & 271 \\
\hline & Średnie & 85 & 12 & 3 & 340 \\
\hline & Wyższe & 81 & 14 & 5 & 288 \\
\hline \multirow{13}{*}{$\begin{array}{l}\text { Grupa społeczna } \\
\text { i zawodowa }\end{array}$} & Kadra kier., spec. z wyższym wykszt. & 81 & 13 & 6 & 114 \\
\hline & Średni personel, technicy & 80 & 20 & & 33 \\
\hline & Pracownicy adm.-biurowi & 90 & 7 & 3 & 68 \\
\hline & Pracownicy usług & 87 & 10 & 3 & 78 \\
\hline & Robotnicy wykwalifikowani & 85 & 10 & 5 & 129 \\
\hline & Robotnicy niewykwalifik. & 78 & 13 & 9 & 57 \\
\hline & Rolnicy & 85 & 11 & 4 & 56 \\
\hline & Pracujący na własny rach. & 86 & 11 & 3 & 53 \\
\hline & Bezrobotni & 87 & 13 & & 34 \\
\hline & Emeryci & 83 & 13 & 5 & 311 \\
\hline & Renciści & 75 & 15 & 10 & 59 \\
\hline & Uczniowie i studenci & 86 & 11 & 4 & 52 \\
\hline & Gospodynie domowe i inni & 83 & 11 & 5 & 73 \\
\hline \multirow{4}{*}{ Pracuje w: } & inst. państw., publicznej & 86 & 10 & 4 & 158 \\
\hline & spółce właścicieli prywatnych i państwa & 87 & 12 & 1 & 96 \\
\hline & sekt. pryw. poza rolnict. & 83 & 11 & 6 & 286 \\
\hline & prywatnym gosp. rolnym & 85 & 12 & 4 & 58 \\
\hline \multirow{5}{*}{$\begin{array}{l}\text { Dochody na jedną } \\
\text { osobę }\end{array}$} & Do 899 zt & 86 & 11 & 3 & 191 \\
\hline & Od $900 \mathrm{zt}$ do $1299 \mathrm{zt}$ & 86 & 11 & 3 & 216 \\
\hline & Od $1300 \mathrm{zł}$ do $1799 \mathrm{zf}$ & 84 & 11 & 5 & 198 \\
\hline & Od $1800 \mathrm{zt}$ do $2499 \mathrm{zt}$ & 83 & 11 & 6 & 128 \\
\hline & 2500 zł i więcej & 80 & 17 & 2 & 144 \\
\hline \multirow{3}{*}{$\begin{array}{l}\text { Ocena własnych } \\
\text { war. mater. }\end{array}$} & Złe & 75 & 18 & 7 & 105 \\
\hline & Średnie & 86 & 10 & 4 & 441 \\
\hline & Dobre & 83 & 12 & 5 & 571 \\
\hline \multirow{5}{*}{$\begin{array}{l}\text { Udział w prakt. } \\
\text { religijnych }\end{array}$} & Kilka razy w tygodniu & 87 & 9 & 4 & 74 \\
\hline & Raz w tygodniu & 82 & 12 & 6 & 467 \\
\hline & 1-2 razy w miesiącu & 86 & 9 & 5 & 173 \\
\hline & Kilka razy w roku & 85 & 13 & 3 & 242 \\
\hline & W ogóle nie uczestniczy & 82 & 14 & 4 & 153 \\
\hline \multirow{4}{*}{$\begin{array}{l}\text { Poglądy } \\
\text { polityczne }\end{array}$} & Lewica & 84 & 14 & 2 & 206 \\
\hline & Centrum & 83 & 14 & 3 & 300 \\
\hline & Prawica & 83 & 12 & 5 & 355 \\
\hline & Trudno powiedzieć & 83 & 9 & 8 & 224 \\
\hline
\end{tabular}


TABELA 3 (cd.)

\begin{tabular}{|c|c|c|c|c|c|c|c|c|c|}
\hline & & \multicolumn{7}{|c|}{$\begin{array}{l}\text { Jakie formy wspierania rodziny, obecnie funkcjonujące lub postulowane, uważa Pan(i) za najbardziej } \\
\text { przydatne i mogące zachęcać do posiadania dzieci? }\end{array}$} & \multirow{3}{*}{$\begin{array}{l}\text { Liczba } \\
\text { osób }\end{array}$} \\
\hline & & $\begin{array}{l}\text { Stworzenie } \\
\text { rodzicom } \\
\text { małych dzieci } \\
\text { możliwości } \\
\text { elastycznego } \\
\text { czasu pracy }\end{array}$ & $\begin{array}{c}\text { System zniżek } \\
\text { dla rodzin } \\
\text { wielodzietnych } \\
\text { (Karta Dużej } \\
\text { Rodziny) }\end{array}$ & $\begin{array}{c}\text { Ulgi } \\
\text { podatkowe } \\
\text { dla osób } \\
\text { wychowują- } \\
\text { cych dzieci }\end{array}$ & $\begin{array}{c}\text { Wysokie zasiłki } \\
\text { dla rodzin } \\
\text { znajdujących się } \\
\text { w trudnej sytuacji } \\
\text { materialnej }\end{array}$ & \begin{tabular}{|c|} 
Korzystne \\
dla matek \\
rozwiązania \\
emerytalne
\end{tabular} & $\begin{array}{l}\text { Żadne } \\
\text { Znich }\end{array}$ & $\begin{array}{c}\text { Trudno } \\
\text { powiedzieć }\end{array}$ & \\
\hline & & $\%$ & $\%$ & $\%$ & $\%$ & $\%$ & $\%$ & $\%$ & \\
\hline \multicolumn{2}{|l|}{ Ogółem } & 20 & 19 & 33 & 17 & 14 & 2 & 3 & 1116 \\
\hline \multirow[t]{2}{*}{ Płeć } & Mężczyżni & 16 & 22 & 35 & 19 & 15 & 2 & 4 & 521 \\
\hline & Kobiety & 23 & 17 & 30 & 16 & 13 & 1 & 2 & 595 \\
\hline \multirow[t]{6}{*}{ Wiek } & 18-24 lata & 18 & 31 & 32 & 21 & 6 & 1 & 3 & 83 \\
\hline & $25-34$ & 24 & 23 & 28 & 13 & 11 & 3 & 3 & 208 \\
\hline & $35-44$ & 21 & 20 & 42 & 13 & 16 & 1 & 1 & 207 \\
\hline & $45-54$ & 18 & 17 & 39 & 21 & 18 & 1 & 2 & 169 \\
\hline & $55-64$ & 27 & 18 & 31 & 21 & 13 & 1 & 3 & 206 \\
\hline & 65 lat i więcej & 12 & 15 & 26 & 18 & 16 & 2 & 5 & 244 \\
\hline \multirow{5}{*}{$\begin{array}{l}\text { Miejsce } \\
\text { zamieszkania }\end{array}$} & Wieś & 20 & 19 & 32 & 21 & 15 & 2 & 3 & 447 \\
\hline & Miasto do 19999 & 20 & 12 & 33 & 16 & 12 & 1 & 5 & 142 \\
\hline & $20000-99999$ & 20 & 20 & 33 & 14 & 15 & 2 & 1 & 245 \\
\hline & $100000-499999$ & 17 & 26 & 30 & 16 & 13 & 1 & 3 & 188 \\
\hline & 500000 i więcej mieszk. & 28 & 16 & 40 & 11 & 12 & 5 & 2 & 94 \\
\hline \multirow[t]{4}{*}{ Wykształcenie } & Podstawowe / gimnazjalne & 14 & 20 & 27 & 20 & 12 & 1 & 5 & 217 \\
\hline & Zasadnicze zawodowe & 16 & 19 & 30 & 23 & 18 & 1 & 3 & 272 \\
\hline & Średnie & 21 & 20 & 33 & 17 & 14 & 2 & 2 & 340 \\
\hline & Wyższe & 26 & 19 & 39 & 10 & 13 & 2 & 2 & 288 \\
\hline \multirow{13}{*}{$\begin{array}{l}\text { Grupa } \\
\text { społeczna } \\
\text { i zawodowa }\end{array}$} & $\begin{array}{l}\text { Kadra kier., spec. } \\
\text { z wyższym wykszt. }\end{array}$ & 31 & 25 & 41 & 9 & 12 & 3 & 1 & 114 \\
\hline & Średni personel, technicy & 28 & 30 & 22 & 16 & & 4 & & 33 \\
\hline & Pracownicy adm.-biurowi & 18 & 15 & 45 & 4 & 13 & 2 & 2 & 68 \\
\hline & Pracownicy usług & 19 & 22 & 38 & 15 & 10 & 1 & & 78 \\
\hline & Robotnicy wykwalifikowani & 19 & 17 & 42 & 15 & 15 & 2 & 2 & 129 \\
\hline & Robotnicy niewykwalifik. & 22 & 13 & 27 & 27 & 20 & 2 & 6 & 56 \\
\hline & Rolnicy & 19 & 17 & 29 & 14 & 18 & 3 & 4 & 56 \\
\hline & Pracujący na własny rach. & 17 & 30 & 38 & 15 & 11 & 5 & 2 & 55 \\
\hline & Bezrobotni & 25 & 16 & 35 & 26 & 20 & 3 & & 34 \\
\hline & Emeryci & 15 & 18 & 26 & 18 & 15 & 1 & 5 & 310 \\
\hline & Renciści & 19 & 12 & 28 & 32 & 15 & & 3 & 59 \\
\hline & Uczniowie i studenci & 17 & 40 & 26 & 22 & 6 & 2 & 2 & 52 \\
\hline & Gospodynie domowe i inni & 24 & 7 & 32 & 25 & 23 & & 3 & 73 \\
\hline \multirow[t]{4}{*}{ Pracuje w: } & inst. państw., publicznej & 24 & 18 & 43 & 15 & 9 & 2 & 1 & 158 \\
\hline & $\begin{array}{l}\text { spółce właścicieli } \\
\text { prywatnych i państwa }\end{array}$ & 23 & 26 & 40 & 8 & 14 & 2 & 4 & 98 \\
\hline & sekt. pryw. poza rolnict. & 21 & 21 & 35 & 15 & 14 & 3 & 1 & 285 \\
\hline & prywatnym gosp. rolnym & 18 & 18 & 34 & 14 & 13 & 3 & 4 & 58 \\
\hline \multirow{5}{*}{$\begin{array}{l}\text { Dochody na } \\
\text { jedną osobę }\end{array}$} & Do $899 \mathrm{zt}$ & 18 & 19 & 29 & 24 & 19 & 1 & 2 & 191 \\
\hline & Od $900 \mathrm{zt}$ do $1299 \mathrm{zf}$ & 19 & 20 & 31 & 19 & 13 & 1 & 3 & 216 \\
\hline & Od $1300 \mathrm{zł}$ do $1799 \mathrm{zł}$ & 24 & 15 & 31 & 16 & 14 & 1 & 2 & 198 \\
\hline & Od $1800 \mathrm{zt}$ do $2499 \mathrm{zt}$ & 14 & 21 & 38 & 10 & 13 & 3 & 1 & 128 \\
\hline & 2500 zł i więcej & 25 & 17 & 38 & 16 & 16 & 1 & 2 & 144 \\
\hline \multirow{3}{*}{$\begin{array}{l}\text { Ocena } \\
\text { whasnych war. } \\
\text { mater. }\end{array}$} & Złe & 18 & 13 & 35 & 22 & 10 & 5 & 5 & 104 \\
\hline & Średnie & 20 & 17 & 29 & 20 & 16 & 2 & 4 & 440 \\
\hline & Dobre & 20 & 22 & 36 & 15 & 14 & 1 & 2 & 573 \\
\hline \multirow{5}{*}{$\begin{array}{l}\text { Udział w prakt. } \\
\text { religijnych }\end{array}$} & Kilka razy w tygodniu & 21 & 13 & 29 & 22 & 12 & 3 & 3 & 74 \\
\hline & Raz w tygodniu & 18 & 19 & 28 & 20 & 15 & 1 & 3 & 466 \\
\hline & $1-2$ razy w miesiącu & 20 & 22 & 40 & 14 & 17 & 2 & 6 & 173 \\
\hline & Kilka razy w roku & 18 & 20 & 35 & 13 & 13 & 3 & 1 & 241 \\
\hline & W ogóle nie uczestniczy & 27 & 19 & 35 & 17 & 10 & 2 & 3 & 155 \\
\hline \multirow{4}{*}{$\begin{array}{l}\text { Poglądy } \\
\text { polityczne }\end{array}$} & Lewica & 24 & 22 & 36 & 11 & 20 & 2 & 1 & 207 \\
\hline & Centrum & 23 & 20 & 35 & 18 & 14 & 1 & 2 & 299 \\
\hline & Prawica & 15 & 18 & 32 & 21 & 15 & 1 & 2 & 355 \\
\hline & Trudno powiedzieć & 19 & 17 & 29 & 16 & 8 & 3 & 8 & 224 \\
\hline
\end{tabular}


TABELA 5

\begin{tabular}{|c|c|c|c|c|c|}
\hline & & \multicolumn{3}{|c|}{$\begin{array}{l}\text { Rząd zapowiada nowe rozwiązania, które mają służyć wspieraniu rodzin } \\
\text { i zachęcać do posiadania dzieci. Czy Pan(i) popiera } \\
\text { gwarancje najniższej emerytury dla matek co najmniej czworga dzieci? }\end{array}$} & \multirow{3}{*}{ Liczba osób } \\
\hline & & Popieram & Jestem przeciwny(a) & Trudno powiedzieć & \\
\hline & & $\%$ & $\%$ & $\%$ & \\
\hline \multicolumn{2}{|l|}{ Ogótem } & 77 & 19 & 4 & 1117 \\
\hline \multirow[t]{2}{*}{ Płeć } & Mężczyżni & 78 & 18 & 4 & 522 \\
\hline & Kobiety & 76 & 20 & 4 & 595 \\
\hline \multirow[t]{6}{*}{ Wiek } & 18-24 lata & 69 & 26 & 5 & 83 \\
\hline & $25-34$ & 72 & 23 & 5 & 208 \\
\hline & $35-44$ & 81 & 16 & 3 & 205 \\
\hline & $45-54$ & 73 & 22 & 5 & 169 \\
\hline & $55-64$ & 76 & 21 & 3 & 207 \\
\hline & 65 lat i więcej & 85 & 12 & 3 & 244 \\
\hline \multirow{5}{*}{$\begin{array}{l}\text { Miejsce } \\
\text { zamieszkania }\end{array}$} & Wieś & 79 & 15 & 6 & 449 \\
\hline & Miasto do 19999 & 82 & 15 & 3 & 142 \\
\hline & $20000-99999$ & 76 & 22 & 1 & 245 \\
\hline & $100000-499999$ & 75 & 22 & 3 & 187 \\
\hline & 500000 i więcej mieszk. & 65 & 28 & 7 & 94 \\
\hline \multirow[t]{4}{*}{ Wykształcenie } & Podstawowe / gimnazjalne & 81 & 15 & 4 & 218 \\
\hline & Zasadnicze zawodowe & 81 & 15 & 4 & 273 \\
\hline & Średnie & 74 & 22 & 4 & 340 \\
\hline & Wyższe & 74 & 21 & 4 & 286 \\
\hline \multirow{13}{*}{$\begin{array}{l}\text { Grupa społeczna } \\
\text { i zawodowa }\end{array}$} & Kadra kier., spec. z wyższym wykszt. & 72 & 23 & 5 & 113 \\
\hline & Średni personel, technicy & 57 & 41 & 2 & 33 \\
\hline & Pracownicy adm.-biurowi & 73 & 20 & 7 & 68 \\
\hline & Pracownicy usług & 78 & 18 & 4 & 78 \\
\hline & Robotnicy wykwalifikowani & 79 & 20 & 1 & 129 \\
\hline & Robotnicy niewykwalifik. & 75 & 18 & 7 & 57 \\
\hline & Rolnicy & 87 & 8 & 5 & 56 \\
\hline & Pracujący na własny rach. & 78 & 20 & 2 & 55 \\
\hline & Bezrobotni & 79 & 17 & 4 & 34 \\
\hline & Emeryci & 82 & 16 & 2 & 311 \\
\hline & Renciści & 75 & 23 & 2 & 59 \\
\hline & Uczniowie i studenci & 67 & 25 & 8 & 52 \\
\hline & Gospodynie domowe i inni & 76 & 16 & 8 & 73 \\
\hline \multirow[t]{4}{*}{ Pracuje w: } & inst. państw., publicznej & 71 & 26 & 4 & 156 \\
\hline & spółce właścicieli prywatnych i państwa & 78 & 19 & 3 & 98 \\
\hline & sekt. pryw. poza rolnict. & 75 & 21 & 4 & 286 \\
\hline & prywatnym gosp. rolnym & 87 & 8 & 4 & 58 \\
\hline \multirow{5}{*}{$\begin{array}{l}\text { Dochody na jedną } \\
\text { osobę }\end{array}$} & Do 899 zł & 80 & 16 & 5 & 191 \\
\hline & Od $900 \mathrm{zł}$ do $1299 \mathrm{zł}$ & 79 & 18 & 3 & 216 \\
\hline & Od $1300 \mathrm{zt}$ do $1799 \mathrm{zt}$ & 77 & 21 & 1 & 196 \\
\hline & Od 1800 zł do 2499 zł & 74 & 19 & 7 & 129 \\
\hline & 2500 zł i więcej & 74 & 23 & 2 & 144 \\
\hline \multirow{3}{*}{$\begin{array}{l}\text { Ocena własnych } \\
\text { war. mater. }\end{array}$} & Złe & 73 & 18 & 9 & 105 \\
\hline & Średnie & 78 & 19 & 3 & 447 \\
\hline & Dobre & 77 & 19 & 4 & 571 \\
\hline \multirow{5}{*}{$\begin{array}{l}\text { Udział w prakt. } \\
\text { religijnych }\end{array}$} & Kilka razy w tygodniu & 92 & 8 & & 74 \\
\hline & Raz w tygodniu & 81 & 14 & 5 & 465 \\
\hline & 1-2 razy w miesiącu & 80 & 14 & 6 & 173 \\
\hline & Kilka razy w roku & 70 & 27 & 3 & 242 \\
\hline & W ogóle nie uczestniczy & 67 & 32 & 1 & 155 \\
\hline \multirow{4}{*}{$\begin{array}{l}\text { Poglądy } \\
\text { polityczne }\end{array}$} & Lewica & 73 & 25 & 2 & 207 \\
\hline & Centrum & 74 & 22 & 4 & 300 \\
\hline & Prawica & 83 & 15 & 2 & 354 \\
\hline & Trudno powiedzieć & 76 & 16 & 7 & 224 \\
\hline
\end{tabular}


TABELA 6

\begin{tabular}{|c|c|c|c|c|c|}
\hline & & \multicolumn{3}{|c|}{$\begin{array}{c}\text { Rząd zapowiada nowe rozwiązania, które mają służyć wspieraniu rodzin } \\
\text { i zachęcać do posiadania dzieci. Czy Pan(i) popiera } \\
\mathbf{3 0 0} \text { zł na wyprawkę szkolną dla każdego ucznia? }\end{array}$} & \multirow[t]{3}{*}{ Liczba osób } \\
\hline & & Popieram & Jestem przeciwny(a) & Trudno powiedzieć & \\
\hline & & $\%$ & $\%$ & $\%$ & \\
\hline \multicolumn{2}{|l|}{ Ogółem } & 75 & 22 & 3 & 1117 \\
\hline \multirow[t]{2}{*}{ Płeć } & Mężczyźni & 75 & 22 & 3 & 522 \\
\hline & Kobiety & 74 & 21 & 5 & 595 \\
\hline \multirow[t]{6}{*}{ Wiek } & 18-24 lata & 83 & 14 & 2 & 83 \\
\hline & $25-34$ & 85 & 12 & 3 & 208 \\
\hline & $35-44$ & 83 & 16 & 2 & 205 \\
\hline & $45-54$ & 68 & 27 & 5 & 169 \\
\hline & $55-64$ & 68 & 29 & 3 & 207 \\
\hline & 65 lat $\mathrm{i}$ więcej & 67 & 27 & 6 & 244 \\
\hline \multirow{5}{*}{$\begin{array}{l}\text { Miejsce } \\
\text { zamieszkania }\end{array}$} & Wieś & 80 & 16 & 3 & 449 \\
\hline & Miasto do 19999 & 70 & 27 & 3 & 142 \\
\hline & $20000-99999$ & 76 & 21 & 3 & 245 \\
\hline & $100000-499999$ & 73 & 23 & 4 & 187 \\
\hline & 500000 i więcej mieszk. & 57 & 36 & 7 & 94 \\
\hline \multirow[t]{4}{*}{ Wykształcenie } & Podstawowe / gimnazjalne & 79 & 13 & 8 & 218 \\
\hline & Zasadnicze zawodowe & 82 & 17 & 1 & 273 \\
\hline & Średnie & 74 & 24 & 2 & 340 \\
\hline & Wyższe & 65 & 30 & 5 & 286 \\
\hline \multirow{13}{*}{$\begin{array}{l}\text { Grupa społeczna } \\
\text { i zawodowa }\end{array}$} & Kadra kier., spec. z wyższym wykszt. & 59 & 36 & 6 & 112 \\
\hline & Średni personel, technicy & 66 & 31 & 3 & 33 \\
\hline & Pracownicy adm.-biurowi & 76 & 19 & 5 & 68 \\
\hline & Pracownicy usług & 83 & 15 & 2 & 78 \\
\hline & Robotnicy wykwalifikowani & 82 & 15 & 4 & 129 \\
\hline & Robotnicy niewykwalifik. & 86 & 10 & 3 & 57 \\
\hline & Rolnicy & 82 & 14 & 4 & 56 \\
\hline & Pracujący na własny rach. & 78 & 22 & & 55 \\
\hline & Bezrobotni & 91 & 9 & & 34 \\
\hline & Emeryci & 67 & 28 & 5 & 311 \\
\hline & Renciści & 72 & 26 & 2 & 59 \\
\hline & Uczniowie i studenci & 78 & 19 & 4 & 52 \\
\hline & Gospodynie domowe i inni & 89 & 9 & 2 & 73 \\
\hline \multirow[t]{4}{*}{ Pracuje w: } & inst. państw., publicznej & 68 & 27 & 6 & 158 \\
\hline & spółce właścicieli prywatnych i państwa & 77 & 20 & 3 & 98 \\
\hline & sekt. pryw. poza rolnict. & 79 & 19 & 2 & 285 \\
\hline & prywatnym gosp. rolnym & 86 & 9 & 4 & 58 \\
\hline \multirow{5}{*}{$\begin{array}{l}\text { Dochody na jedną } \\
\text { osobę }\end{array}$} & Do 899 zt & 85 & 13 & 3 & 191 \\
\hline & Od $900 \mathrm{zf}$ do $1299 \mathrm{zf}$ & 79 & 16 & 6 & 215 \\
\hline & Od 1300 zł do 1799 zł & 69 & 30 & 1 & 198 \\
\hline & Od $1800 \mathrm{zt}$ do $2499 \mathrm{zt}$ & 70 & 24 & 6 & 129 \\
\hline & 2500 zł i więcej & 64 & 31 & 5 & 144 \\
\hline \multirow{3}{*}{$\begin{array}{l}\text { Ocena własnych } \\
\text { war. mater. }\end{array}$} & Zte & 73 & 24 & 4 & 105 \\
\hline & Średnie & 74 & 21 & 5 & 439 \\
\hline & Dobre & 76 & 21 & 3 & 573 \\
\hline \multirow{5}{*}{$\begin{array}{l}\text { Udział w prakt. } \\
\text { religijnych }\end{array}$} & Kilka razy w tygodniu & 81 & 12 & 6 & 74 \\
\hline & Raz w tygodniu & 75 & 20 & 4 & 467 \\
\hline & $1-2$ razy w miesiącu & 83 & 15 & 2 & 172 \\
\hline & Kilka razy w roku & 73 & 23 & 4 & 242 \\
\hline & W ogóle nie uczestniczy & 64 & 34 & 2 & 155 \\
\hline \multirow{4}{*}{$\begin{array}{l}\text { Poglady } \\
\text { polityczne }\end{array}$} & Lewica & 63 & 34 & 3 & 205 \\
\hline & Centrum & 75 & 22 & 3 & 300 \\
\hline & Prawica & 78 & 20 & 2 & 355 \\
\hline & Trudno powiedzieć & 79 & 14 & 7 & 224 \\
\hline
\end{tabular}


TABELA 7

\begin{tabular}{|c|c|c|c|c|c|}
\hline & & \multicolumn{3}{|c|}{$\begin{array}{l}\text { Rząd zapowiada nowe rozwiązania, które mają służyć wspieraniu rodzin } \\
\text { i zachęcać do posiadania dzieci. Czy Pan(i) popiera } \\
\text { wydłużenie urlopu rodzicielskiego o } 3 \text { miesiące w przypadku szybkiego } \\
\text { urodzenia kolejnego dziecka (w ciagu } 2 \text { lat od narodzin poprzedniego)? }\end{array}$} & \multirow[t]{3}{*}{$\begin{array}{l}\text { Liczba } \\
\text { osób }\end{array}$} \\
\hline & & Popieram & Jestem przeciwny(a) & Trudno powiedzieć & \\
\hline & & $\%$ & $\%$ & $\%$ & \\
\hline \multicolumn{2}{|l|}{ Ogółem } & 80 & 14 & 6 & 1118 \\
\hline \multirow[t]{2}{*}{ Płeć } & Mężczyźni & 80 & 12 & 8 & 522 \\
\hline & Kobiety & 80 & 15 & 5 & 596 \\
\hline \multirow[t]{6}{*}{ Wiek } & 18-24 lata & 79 & 15 & 6 & 83 \\
\hline & $25-34$ & 84 & 14 & 3 & 208 \\
\hline & $35-44$ & 83 & 14 & 3 & 207 \\
\hline & $45-54$ & 77 & 15 & 8 & 169 \\
\hline & $55-64$ & 80 & 12 & 8 & 207 \\
\hline & 65 lat i więcej & 77 & 13 & 10 & 244 \\
\hline \multirow{5}{*}{$\begin{array}{l}\text { Miejsce } \\
\text { zamieszkania }\end{array}$} & Wieś & 83 & 10 & 7 & 449 \\
\hline & Miasto do 19999 & 75 & 18 & 7 & 142 \\
\hline & $20000-99999$ & 79 & 14 & 6 & 245 \\
\hline & $100000-499999$ & 82 & 15 & 3 & 188 \\
\hline & 500000 i więcej mieszk. & 71 & 21 & 8 & 94 \\
\hline \multirow[t]{4}{*}{ Wykształcenie } & Podstawowe / gimnazjalne & 81 & 9 & 10 & 218 \\
\hline & Zasadnicze zawodowe & 87 & 7 & 6 & 273 \\
\hline & Średnie & 81 & 14 & 5 & 340 \\
\hline & Wyższe & 72 & 23 & 5 & 288 \\
\hline \multirow{13}{*}{$\begin{array}{l}\text { Grupa społeczna } \\
\text { i zawodowa }\end{array}$} & Kadra kier., spec. z wyższym wykszt. & 75 & 21 & 3 & 114 \\
\hline & Średni personel, technicy & 69 & 25 & 6 & 33 \\
\hline & Pracownicy adm.biurowi & 76 & 20 & 4 & 68 \\
\hline & Pracownicy usług & 81 & 15 & 4 & 78 \\
\hline & Robotnicy wykwalifikowani & 82 & 13 & 5 & 129 \\
\hline & Robotnicy niewykwalifik. & 89 & 3 & 8 & 57 \\
\hline & Rolnicy & 92 & 3 & 4 & 56 \\
\hline & Pracujący na własny rach. & 77 & 18 & 5 & 55 \\
\hline & Bezrobotni & 85 & 10 & 5 & 34 \\
\hline & Emeryci & 78 & 13 & 10 & 311 \\
\hline & Renciści & 87 & 7 & 7 & 59 \\
\hline & Uczniowie i studenci & 72 & 18 & 11 & 52 \\
\hline & Gospodynie domowe i inni & 88 & 11 & 1 & 73 \\
\hline \multirow[t]{4}{*}{ Pracuje w: } & inst. państw., publicznej & 79 & 15 & 6 & 158 \\
\hline & spółce właścicieli prywatnych i państwa & 81 & 17 & 3 & 98 \\
\hline & sekt. pryw. poza rolnict. & 78 & 17 & 5 & 286 \\
\hline & prywatnym gosp. rolnym & 93 & 3 & 4 & 58 \\
\hline \multirow{5}{*}{$\begin{array}{l}\text { Dochody na jedną } \\
\text { osobęe }\end{array}$} & Do 899 zt & 84 & 11 & 5 & 191 \\
\hline & Od $900 \mathrm{zł}$ do $1299 \mathrm{zł}$ & 83 & 10 & 6 & 216 \\
\hline & Od 1300 zł do 1799 zf & 76 & 17 & 7 & 198 \\
\hline & Od $1800 \mathrm{z} \nmid$ do $2499 \mathrm{zt}$ & 85 & 9 & 6 & 129 \\
\hline & 2500 zt i więcej & 73 & 23 & 4 & 144 \\
\hline \multirow{3}{*}{$\begin{array}{l}\text { Ocena własnych } \\
\text { war. mater. }\end{array}$} & Zte & 77 & 11 & 11 & 105 \\
\hline & Średnie & 80 & 12 & 8 & 441 \\
\hline & Dobre & 81 & 15 & 4 & 573 \\
\hline \multirow{5}{*}{$\begin{array}{l}\text { Udział w prakt. } \\
\text { religijnych }\end{array}$} & Kilka razy w tygodniu & 85 & 7 & 8 & 74 \\
\hline & Raz w tygodniu & 81 & 13 & 6 & 467 \\
\hline & 1-2 razy w miesiącu & 86 & 8 & 6 & 173 \\
\hline & Kilka razy w roku & 81 & 12 & 7 & 242 \\
\hline & W ogóle nie uczestniczy & 68 & 28 & 4 & 155 \\
\hline \multirow{4}{*}{$\begin{array}{l}\text { Poglądy } \\
\text { polityczne }\end{array}$} & Lewica & 74 & 21 & 5 & 207 \\
\hline & Centrum & 80 & 15 & 5 & 300 \\
\hline & Prawica & 85 & 11 & 4 & 355 \\
\hline & Trudno powiedzieć & 80 & 8 & 12 & 224 \\
\hline
\end{tabular}


TABELA 8

\begin{tabular}{|c|c|c|c|c|c|}
\hline & & \multicolumn{3}{|c|}{$\begin{array}{l}\text { Rząd zapowiada nowe rozwiązania, które mają służyć wspieraniu rodzin } \\
\text { i zachęcać do posiadania dzieci. Czy Pan(i) popiera } \\
\text { ułatwienia dla matek-studentek w godzeniu studiów i macierzynstwa? }\end{array}$} & \multirow{3}{*}{ Liczba osób } \\
\hline & & Popieram & Jestem przeciwny(a) & Trudno powiedzieć & \\
\hline & & $\%$ & $\%$ & $\%$ & \\
\hline \multicolumn{2}{|l|}{ Ogółem } & 89 & 6 & 5 & 1117 \\
\hline \multirow[t]{2}{*}{ Płeć } & Mężczyźni & 85 & 9 & 7 & 521 \\
\hline & Kobiety & 93 & 3 & 4 & 596 \\
\hline \multirow[t]{6}{*}{ Wiek } & 18-24 lata & 92 & 5 & 4 & 83 \\
\hline & $25-34$ & 95 & 4 & 1 & 207 \\
\hline & $35-44$ & 91 & 6 & 3 & 207 \\
\hline & $45-54$ & 87 & 7 & 6 & 169 \\
\hline & $55-64$ & 89 & 6 & 6 & 207 \\
\hline & 65 lat $i$ więcej & 83 & 7 & 10 & 244 \\
\hline \multirow{5}{*}{$\begin{array}{l}\text { Miejsce } \\
\text { zamieszkania }\end{array}$} & Wieś & 89 & 4 & 8 & 449 \\
\hline & Miasto do 19999 & 89 & 7 & 4 & 142 \\
\hline & $20000-99999$ & 92 & 5 & 3 & 245 \\
\hline & $100000-499999$ & 89 & 8 & 3 & 187 \\
\hline & 500000 i więcej mieszk. & 83 & 10 & 7 & 94 \\
\hline \multirow[t]{4}{*}{ Wykształcenie } & Podstawowe / gimnazjalne & 84 & 6 & 10 & 218 \\
\hline & Zasadnicze zawodowe & 90 & 4 & 6 & 273 \\
\hline & Średnie & 90 & 7 & 3 & 340 \\
\hline & Wyższe & 91 & 7 & 2 & 286 \\
\hline \multirow{13}{*}{$\begin{array}{l}\text { Grupa społeczna } \\
\text { i zawodowa }\end{array}$} & Kadra kier., spec. z wyższym wykszt. & 91 & 6 & 3 & 113 \\
\hline & Średni personel, technicy & 86 & 11 & 2 & 33 \\
\hline & Pracownicy adm.-biurowi & 94 & 3 & 4 & 68 \\
\hline & Pracownicy usług & 92 & 5 & 3 & 78 \\
\hline & Robotnicy wykwalifikowani & 91 & 4 & 5 & 129 \\
\hline & Robotnicy niewykwalifik. & 86 & 5 & 9 & 57 \\
\hline & Rolnicy & 87 & 6 & 7 & 56 \\
\hline & Pracujący na własny rach. & 88 & 11 & 1 & 55 \\
\hline & Bezrobotni & 93 & 4 & 3 & 34 \\
\hline & Emeryci & 85 & 6 & 8 & 311 \\
\hline & Renciści & 89 & 5 & 6 & 59 \\
\hline & Uczniowie i studenci & 90 & 4 & 6 & 52 \\
\hline & Gospodynie domowe i inni & 94 & 6 & & 73 \\
\hline \multirow[t]{4}{*}{ Pracuje w: } & inst. państw., publicznej & 94 & 3 & 3 & 158 \\
\hline & spółce właścicieli prywatnych i państwa & 84 & 12 & 5 & 98 \\
\hline & sekt. pryw. poza rolnict. & 91 & 5 & 4 & 285 \\
\hline & prywatnym gosp. rolnym & 86 & 7 & 6 & 58 \\
\hline \multirow{5}{*}{$\begin{array}{l}\text { Dochody na jedną } \\
\text { osobęe }\end{array}$} & Do $899 \mathrm{zł}$ & 89 & 6 & 5 & 191 \\
\hline & Od $900 \mathrm{zł}$ do $1299 \mathrm{zł}$ & 89 & 4 & 6 & 216 \\
\hline & Od $1300 \mathrm{zł}$ do $1799 \mathrm{zł}$ & 90 & 7 & 3 & 198 \\
\hline & Od $1800 \mathrm{zł}$ do $2499 \mathrm{zf}$ & 93 & 4 & 3 & 129 \\
\hline & 2500 zł i więcej & 90 & 7 & 3 & 144 \\
\hline \multirow{3}{*}{$\begin{array}{l}\text { Ocena własnych } \\
\text { war. mater. }\end{array}$} & Z $\mathrm{ke}$ & 78 & 11 & 11 & 105 \\
\hline & Średnie & 88 & 6 & 7 & 439 \\
\hline & Dobre & 92 & 5 & 3 & 573 \\
\hline \multirow{5}{*}{$\begin{array}{l}\text { Udział w prakt. } \\
\text { religijnych }\end{array}$} & Kilka razy w tygodniu & 94 & 1 & 5 & 74 \\
\hline & Raz w tygodniu & 91 & 5 & 5 & 467 \\
\hline & $1-2$ razy w miesiącu & 90 & 5 & 5 & 173 \\
\hline & Kilka razy w roku & 88 & 6 & 6 & 242 \\
\hline & W ogóle nie uczestniczy & 83 & 13 & 4 & 155 \\
\hline \multirow{4}{*}{$\begin{array}{l}\text { Poglądy } \\
\text { polityczne }\end{array}$} & Lewica & 91 & 7 & 2 & 207 \\
\hline & Centrum & 88 & 8 & 3 & 300 \\
\hline & Prawica & 90 & 5 & 5 & 353 \\
\hline & Trudno powiedzieć & 87 & 3 & 11 & 224 \\
\hline
\end{tabular}


TABELA 9

\begin{tabular}{|c|c|c|c|c|c|}
\hline & & \multicolumn{3}{|c|}{$\begin{array}{l}\text { Rząd zapowiada nowe rozwiązania, które mają służyć wspieraniu rodzin } \\
\text { i zachęcać do posiadania dzieci. Czy Pan(i) popiera } \\
\text { bony na sport i kulturę dla młodzieży? }\end{array}$} & \multirow[t]{3}{*}{ Liczba osób } \\
\hline & & Popieram & Jestem przeciwny(a) & Trudno powiedzieć & \\
\hline & & $\%$ & $\%$ & $\%$ & \\
\hline \multicolumn{2}{|l|}{ Ogółem } & 85 & 10 & 5 & 1117 \\
\hline \multirow{2}{*}{ Płeć } & Mężczyźni & 82 & 13 & 5 & 522 \\
\hline & Kobiety & 88 & 7 & 5 & 595 \\
\hline \multirow[t]{6}{*}{ Wiek } & 18-24 lata & 92 & 3 & 5 & 83 \\
\hline & $25-34$ & 88 & 9 & 3 & 208 \\
\hline & $35-44$ & 89 & 8 & 3 & 207 \\
\hline & $45-54$ & 83 & 12 & 5 & 169 \\
\hline & $55-64$ & 86 & 11 & 3 & 207 \\
\hline & 65 lat $i$ więcej & 78 & 12 & 10 & 244 \\
\hline \multirow{5}{*}{$\begin{array}{l}\text { Miejsce } \\
\text { zamieszkania }\end{array}$} & Wieś & 85 & 9 & 6 & 449 \\
\hline & Miasto do 19999 & 89 & 9 & 2 & 142 \\
\hline & $20000-99999$ & 83 & 12 & 5 & 245 \\
\hline & $100000-499999$ & 87 & 9 & 4 & 188 \\
\hline & 500000 i więcej mieszk. & 80 & 12 & 7 & 94 \\
\hline \multirow[t]{4}{*}{ Wykształcenie } & Podstawowe / gimnazjalne & 83 & 9 & 8 & 218 \\
\hline & Zasadnicze zawodowe & 89 & 8 & 3 & 273 \\
\hline & Średnie & 88 & 9 & 3 & 340 \\
\hline & Wyższe & 80 & 14 & 6 & 287 \\
\hline \multirow{13}{*}{$\begin{array}{l}\text { Grupa społeczna } \\
\text { i zawodowa }\end{array}$} & Kadra kier., spec. z wyższym wykszt. & 81 & 13 & 6 & 114 \\
\hline & Średni personel, technicy & 84 & 5 & 11 & 33 \\
\hline & Pracownicy adm.-biurowi & 92 & 6 & 2 & 68 \\
\hline & Pracownicy usług & 92 & 8 & & 78 \\
\hline & Robotnicy wykwalifikowani & 87 & 10 & 3 & 129 \\
\hline & Robotnicy niewykwalifik. & 84 & 9 & 6 & 57 \\
\hline & Rolnicy & 81 & 15 & 4 & 56 \\
\hline & Pracujący na własny rach. & 79 & 13 & 9 & 55 \\
\hline & Bezrobotni & 91 & 5 & 4 & 34 \\
\hline & Emeryci & 80 & 12 & 8 & 310 \\
\hline & Renciści & 88 & 12 & & 59 \\
\hline & Uczniowie i studenci & 88 & 9 & 4 & 52 \\
\hline & Gospodynie domowe i inni & 96 & 4 & & 73 \\
\hline \multirow[t]{4}{*}{ Pracuje w: } & inst. państw., publicznej & 88 & 7 & 5 & 158 \\
\hline & spółce właścicieli prywatnych i państwa & 84 & 14 & 2 & 98 \\
\hline & sekt. pryw. poza rolnict. & 85 & 10 & 5 & 286 \\
\hline & prywatnym gosp. rolnym & 83 & 12 & 5 & 58 \\
\hline \multirow{5}{*}{$\begin{array}{l}\text { Dochody na jedną } \\
\text { osobę }\end{array}$} & Do 899 zt & 86 & 11 & 4 & 191 \\
\hline & Od 900 zł do $1299 \mathrm{zt}$ & 87 & 8 & 5 & 216 \\
\hline & Od 1300 zt do 1799 zt & 87 & 9 & 4 & 198 \\
\hline & Od 1800 zł do 2499 zł & 85 & 9 & 5 & 129 \\
\hline & 2500 zti więcej & 81 & 16 & 2 & 144 \\
\hline \multirow{3}{*}{$\begin{array}{l}\text { Ocena własnych } \\
\text { war. mater. }\end{array}$} & Złe & 78 & 15 & 7 & 105 \\
\hline & Średnie & 85 & 10 & 5 & 441 \\
\hline & Dobre & 86 & 9 & 5 & 572 \\
\hline \multirow{5}{*}{$\begin{array}{l}\text { Udzial w prakt. } \\
\text { religijnych }\end{array}$} & Kilka razy w tygodniu & 84 & 9 & 7 & 74 \\
\hline & Raz w tygodniu & 86 & 9 & 4 & 466 \\
\hline & 1-2 razy w miesiącu & 86 & 9 & 5 & 173 \\
\hline & Kilka razy w roku & 85 & 11 & 4 & 242 \\
\hline & W ogóle nie uczestniczy & 82 & 13 & 5 & 155 \\
\hline \multirow{4}{*}{$\begin{array}{l}\text { Poglądy } \\
\text { polityczne }\end{array}$} & Lewica & 84 & 12 & 5 & 206 \\
\hline & Centrum & 86 & 9 & 5 & 300 \\
\hline & Prawica & 83 & 13 & 4 & 355 \\
\hline & Trudno powiedzieć & 88 & 6 & 6 & 224 \\
\hline
\end{tabular}


TABELA 10

\begin{tabular}{|c|c|c|c|c|c|c|}
\hline & & \multicolumn{4}{|c|}{ Które z tych rozwiązań byłyby, Pana(i) zdaniem, najbardziej potrzebne? } & \multirow{3}{*}{$\begin{array}{l}\text { Liczba } \\
\text { osób }\end{array}$} \\
\hline & & $\begin{array}{l}\text { Bezpłatne leki } \\
\text { dla kobiet } \\
\text { w ciąży }\end{array}$ & $\begin{array}{c}\text { Gwarancje } \\
\text { najniższej } \\
\text { emerytury dla } \\
\text { matek co najmniej } \\
\text { czworga dzieci }\end{array}$ & $\begin{array}{c}300 \text { zł na } \\
\text { wyprawkę } \\
\text { szkolną dla } \\
\text { każdego ucznia }\end{array}$ & $\begin{array}{c}\text { Wydłużenie urlopu } \\
\text { rodzicielskiegoo o } 3 \text { miesiące } \\
\text { w przypadku szybkiego } \\
\text { urodzenia kolejnego dziecka } \\
\text { (w ciągu } 2 \text { lat od narodzin } \\
\text { poprzedniego) }\end{array}$ & \\
\hline & & $\%$ & $\%$ & $\%$ & $\%$ & \\
\hline \multicolumn{2}{|l|}{ Ogółem } & 34 & 40 & 39 & 31 & 1118 \\
\hline \multirow[t]{2}{*}{ Płeć } & Mężczyźni & 39 & 38 & 39 & 29 & 522 \\
\hline & Kobiety & 29 & 41 & 39 & 33 & 596 \\
\hline \multirow[t]{6}{*}{ Wiek } & 18-24 lata & 34 & 24 & 56 & 24 & 83 \\
\hline & $25-34$ & 37 & 35 & 48 & 28 & 208 \\
\hline & $35-44$ & 37 & 41 & 47 & 28 & 207 \\
\hline & $45-54$ & 34 & 43 & 36 & 35 & 169 \\
\hline & $55-64$ & 31 & 43 & 31 & 37 & 207 \\
\hline & 65 lat i więcej & 30 & 42 & 28 & 30 & 244 \\
\hline \multirow{5}{*}{$\begin{array}{l}\text { Miejsce } \\
\text { zamieszkania }\end{array}$} & Wieś & 31 & 41 & 40 & 31 & 449 \\
\hline & Miasto do 19999 & 25 & 38 & 38 & 36 & 142 \\
\hline & $20000-99999$ & 36 & 42 & 41 & 27 & 245 \\
\hline & $100000-499999$ & 40 & 37 & 39 & 30 & 188 \\
\hline & $500000 \mathrm{i}$ więcej mieszk. & 36 & 31 & 28 & 32 & 94 \\
\hline \multirow[t]{4}{*}{ Wykształcenie } & Podstawowe / gimnazjalne & 36 & 35 & 41 & 26 & 218 \\
\hline & Zasadnicze zawodowe & 34 & 43 & 48 & 31 & 273 \\
\hline & Średnie & 30 & 40 & 36 & 32 & 340 \\
\hline & Wyższe & 36 & 40 & 32 & 32 & 288 \\
\hline \multirow{13}{*}{$\begin{array}{l}\text { Grupa } \\
\text { społeczna } \\
\text { i zawodowa }\end{array}$} & Kadra kier., spec. z wyższym wykszt. & 36 & 40 & 30 & 35 & 114 \\
\hline & Średni personel, technicy & 32 & 37 & 35 & 31 & 33 \\
\hline & Pracownicy adm.-biurowi & 40 & 34 & 44 & 28 & 68 \\
\hline & Pracownicy usług & 36 & 39 & 47 & 32 & 78 \\
\hline & Robotnicy wykwalifikowani & 44 & 33 & 47 & 29 & 129 \\
\hline & Robotnicy niewykwalifik. & 18 & 39 & 48 & 40 & 57 \\
\hline & Rolnicy & 29 & 57 & 38 & 31 & 56 \\
\hline & Pracujący na własny rach. & 39 & 42 & 25 & 28 & 55 \\
\hline & Bezrobotni & 33 & 36 & 51 & 30 & 34 \\
\hline & Emeryci & 30 & 42 & 30 & 30 & 311 \\
\hline & Renciści & 26 & 40 & 41 & 46 & 59 \\
\hline & Uczniowie i studenci & 39 & 21 & 55 & 17 & 52 \\
\hline & Gospodynie domowe i inni & 33 & 48 & 53 & 25 & 73 \\
\hline \multirow[t]{4}{*}{ Pracuje w: } & inst. państw., publicznej & 36 & 36 & 33 & 39 & 158 \\
\hline & spółce właścicieli prywatnych i państwa & 34 & 35 & 46 & 35 & 98 \\
\hline & sekt. pryw. poza rolnict. & 38 & 39 & 43 & 26 & 286 \\
\hline & prywatnym gosp. rolnym & 33 & 52 & 39 & 32 & 58 \\
\hline \multirow{5}{*}{$\begin{array}{l}\text { Dochody na } \\
\text { jedną osobę }\end{array}$} & Do 899 zł & 32 & 44 & 50 & 29 & 191 \\
\hline & Od 900 zł do $1299 \mathrm{zf}$ & 33 & 43 & 41 & 28 & 216 \\
\hline & Od 1300 zł do 1799 zł & 37 & 36 & 42 & 28 & 198 \\
\hline & Od 1800 zł do 2499 zł & 39 & 38 & 33 & 37 & 129 \\
\hline & 2500 zti więcej & 34 & 42 & 28 & 39 & 144 \\
\hline \multirow{3}{*}{$\begin{array}{l}\text { Ocena własnych } \\
\text { war. mater. }\end{array}$} & Złe & 28 & 32 & 47 & 27 & 105 \\
\hline & Średnie & 34 & 39 & 39 & 32 & 441 \\
\hline & Dobre & 34 & 41 & 38 & 31 & 573 \\
\hline \multirow{5}{*}{$\begin{array}{l}\text { Udział w prakt. } \\
\text { religijnych }\end{array}$} & Kilka razy w tygodniu & 27 & 51 & 41 & 29 & 74 \\
\hline & Raz w tygodniu & 32 & 42 & 39 & 35 & 467 \\
\hline & $1-2$ razy w miesiącu & 40 & 41 & 44 & 25 & 173 \\
\hline & Kilka razy w roku & 33 & 34 & 39 & 33 & 242 \\
\hline & W ogóle nie uczestniczy & 38 & 35 & 33 & 24 & 155 \\
\hline \multirow{4}{*}{$\begin{array}{l}\text { Poglądy } \\
\text { polityczne }\end{array}$} & Lewica & 34 & 39 & 32 & 27 & 207 \\
\hline & Centrum & 39 & 36 & 43 & 28 & 300 \\
\hline & Prawica & 33 & 44 & 37 & 37 & 355 \\
\hline & Trudno powiedzieć & 28 & 37 & 44 & 30 & 224 \\
\hline
\end{tabular}


TABELA 10 (cd.)

\begin{tabular}{|c|c|c|c|c|c|c|}
\hline & & \multicolumn{4}{|c|}{ Które z tych rozwiązań byłyby, Pana(i) zdaniem, najbardziej potrzebne? } & \multirow{3}{*}{$\begin{array}{l}\text { Liczba } \\
\text { osób }\end{array}$} \\
\hline & & $\begin{array}{l}\text { Ułatwienia dla matek- } \\
\text { studentek w godzeniu } \\
\text { studiów i macierzyństwa }\end{array}$ & $\begin{array}{l}\text { Bony na sport i kulturę } \\
\text { dla młodzieży }\end{array}$ & Żadne z nich & $\begin{array}{c}\text { Trudno } \\
\text { powiedzieć }\end{array}$ & \\
\hline & & $\%$ & $\%$ & $\%$ & $\%$ & \\
\hline \multicolumn{2}{|l|}{ Ogółem } & 22 & 15 & 2 & 3 & 1118 \\
\hline \multirow{2}{*}{ Płeć } & Mężczyźni & 17 & 15 & 3 & 3 & 522 \\
\hline & Kobiety & 26 & 15 & 2 & 2 & 596 \\
\hline \multirow[t]{6}{*}{ Wiek } & 18-24 lata & 35 & 17 & 1 & 1 & 83 \\
\hline & $25-34$ & 18 & 17 & 3 & 1 & 208 \\
\hline & $35-44$ & 15 & 19 & 1 & 2 & 207 \\
\hline & $45-54$ & 24 & 13 & 2 & 1 & 169 \\
\hline & $55-64$ & 27 & 14 & 2 & 2 & 207 \\
\hline & 65 lat i więcej & 19 & 13 & 4 & 7 & 244 \\
\hline \multirow{5}{*}{$\begin{array}{l}\text { Miejsce } \\
\text { zamieszkania }\end{array}$} & Wieś & 20 & 13 & 2 & 4 & 449 \\
\hline & Miasto do 19999 & 27 & 16 & 2 & 3 & 142 \\
\hline & $20000-99999$ & 23 & 13 & 1 & 2 & 245 \\
\hline & $100000-499999$ & 19 & 18 & 4 & 2 & 188 \\
\hline & 500000 i więcej mieszk. & 21 & 24 & 7 & 2 & 94 \\
\hline \multirow[t]{4}{*}{ Wykształcenie } & Podstawowe / gimnazjalne & 19 & 10 & 3 & 7 & 218 \\
\hline & Zasadnicze zawodowe & 14 & 16 & 1 & 2 & 273 \\
\hline & Średnie & 28 & 15 & 2 & 3 & 340 \\
\hline & Wyższe & 23 & 19 & 4 & 1 & 288 \\
\hline \multirow{13}{*}{$\begin{array}{l}\text { Grupa } \\
\text { społeczna } \\
\text { i zawodowa }\end{array}$} & Kadra kier., spec. z wyższym wykszt. & 28 & 17 & 4 & & 114 \\
\hline & Średni personel, technicy & 25 & 17 & 2 & 5 & 33 \\
\hline & Pracownicy adm.biurowi & 22 & 20 & & 2 & 68 \\
\hline & Pracownicy usług & 26 & 6 & 2 & & 78 \\
\hline & Robotnicy wykwalifikowani & 15 & 19 & 3 & 1 & 129 \\
\hline & Robotnicy niewykwalifik. & 13 & 24 & & 6 & 57 \\
\hline & Rolnicy & 11 & 11 & 2 & 4 & 56 \\
\hline & Pracujący na własny rach. & 21 & 22 & 5 & & 55 \\
\hline & Bezrobotni & 17 & 14 & 6 & 1 & 34 \\
\hline & Emeryci & 24 & 14 & 3 & 5 & 311 \\
\hline & Renciści & 20 & 11 & & 4 & 59 \\
\hline & Uczniowie i studenci & 42 & 14 & 2 & 2 & 52 \\
\hline & Gospodynie domowe i inni & 12 & 14 & 1 & & 73 \\
\hline \multirow[t]{4}{*}{ Pracuje w: } & inst. państw., publicznej & 23 & 22 & 1 & 2 & 158 \\
\hline & spółce właścicieli prywatnych i państwa & 22 & 14 & 3 & 1 & 98 \\
\hline & sekt. pryw. poza rolnict. & 20 & 17 & 3 & 1 & 286 \\
\hline & prywatnym gosp. rolnym & 15 & 10 & 2 & 4 & 58 \\
\hline \multirow{5}{*}{$\begin{array}{l}\text { Dochody na } \\
\text { jedną osobę }\end{array}$} & Do 899 zł & 20 & 11 & 1 & 3 & 191 \\
\hline & Od $900 \mathrm{z}$ do $1299 \mathrm{zt}$ & 20 & 13 & 2 & 4 & 216 \\
\hline & Od 1300 zł do $1799 \mathrm{z} \nmid$ & 22 & 19 & 3 & 0 & 198 \\
\hline & Od $1800 \mathrm{zt}$ do $2499 \mathrm{zł}$ & 24 & 17 & 1 & 1 & 129 \\
\hline & 2500 zł i więcej & 23 & 16 & 5 & 0 & 144 \\
\hline \multirow{3}{*}{$\begin{array}{l}\text { Ocena własnych } \\
\text { war. mater. }\end{array}$} & Zte & 17 & 17 & 1 & 4 & 105 \\
\hline & Średnie & 17 & 17 & 2 & 4 & 441 \\
\hline & Dobre & 26 & 14 & 3 & 2 & 573 \\
\hline \multirow{5}{*}{$\begin{array}{l}\text { Udział w prakt. } \\
\text { religijnych }\end{array}$} & Kilka razy w tygodniu & 18 & 16 & 1 & 3 & 74 \\
\hline & Raz w tygodniu & 22 & 13 & 2 & 4 & 467 \\
\hline & 1-2 razy w miesiącu & 17 & 14 & 2 & 2 & 173 \\
\hline & Kilka razy w roku & 23 & 18 & 2 & 1 & 242 \\
\hline & W ogóle nie uczestniczy & 26 & 20 & 4 & 1 & 155 \\
\hline \multirow{4}{*}{$\begin{array}{l}\text { Poglądy } \\
\text { polityczne }\end{array}$} & Lewica & 26 & 22 & 3 & 1 & 207 \\
\hline & Centrum & 23 & 15 & 2 & 2 & 300 \\
\hline & Prawica & 23 & 10 & 3 & 2 & 355 \\
\hline & Trudno powiedzieć & 14 & 16 & 2 & 7 & 224 \\
\hline
\end{tabular}

